
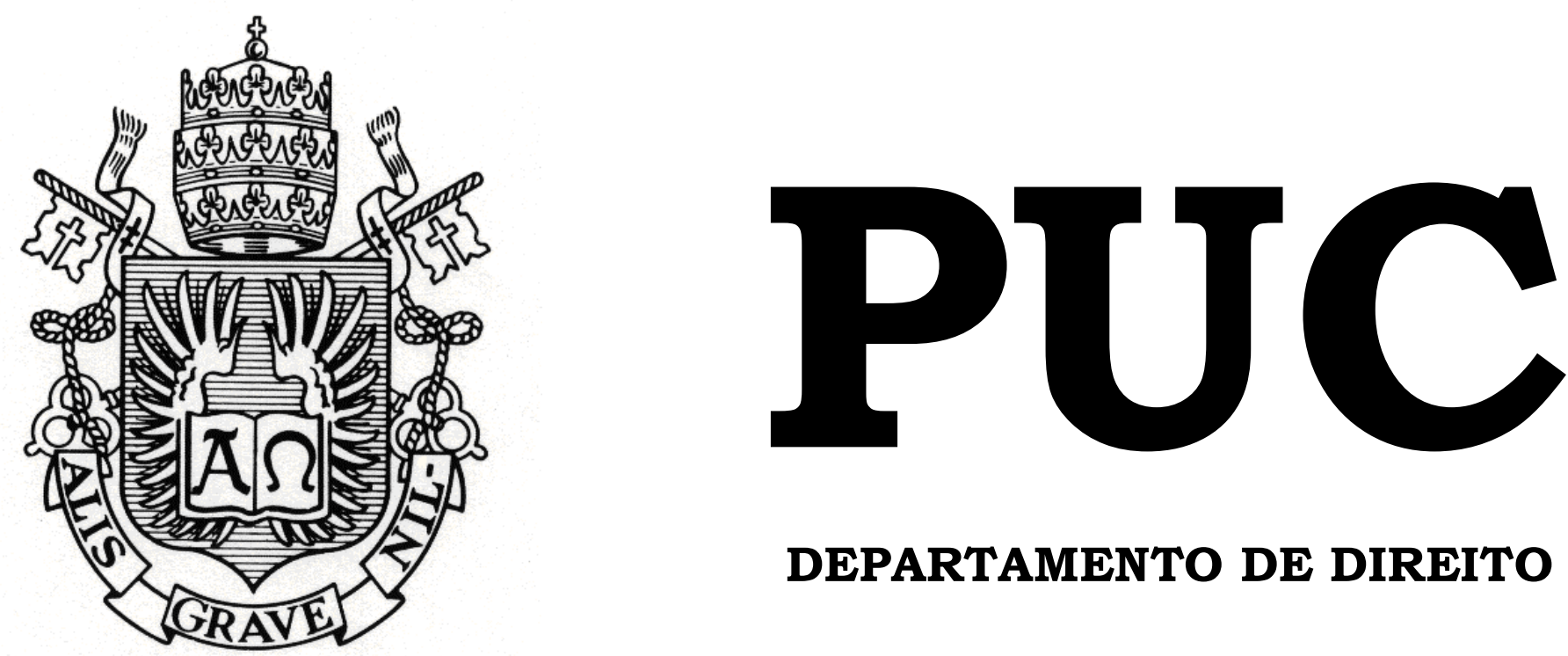

DEPARTAMENTO DE DIREITO

\title{
CONFLITO DE INTERESSES NO ÂMBITO DO DIREITO SOCIETÁRIO.
}

por

JANDRA VICTORIA MUÑOZ RIVERA

ORIENTADOR(A): NORMA PARENTE

2013.1

PONTIFÍCIA UNIVERSIDADE CATÓLICA DO RIO DE JANEIRO

RUA MARQUÊS DE SÃO VICENTE, 225 - CEP 22453-900

RIO DE JANEIRO - BRASIL 


\title{
CONFLITO DE INTERESSES NO ÂMBITO DO DIREITO SOCIETÁRIO.
}

por

\author{
JANDRA VICTORIA MUÑOZ RIVERA
}

Monografia

apresentada

ao

Departamento de Direito da Pontifícia

Universidade Católica do Rio de

Janeiro (PUC-Rio) para a obtenção do

Título de Bacharel em Direito.

Orientador(a): Norma Parente 
Aos meus pais que são referência de disciplina e sucesso. Ao Leonardo, com quem tenho uma dívida incalculável pela paciência e companheirismo. 


\section{RESUMO}

Este trabalho tem como objetivo, analisar e aprofundar o estudo do tema do conflito de interesses nas mais variadas esferas das Sociedades Anônimas, sob a ótica da Lei 6.404/76 ("Lei das S.A."). Para tanto, buscou-se traçar um paralelo entre as principais correntes doutrinárias que tratam da matéria e as distinções entre o conflito de interesse formal e material tal. Far-se-á uma breve análise dos principais casos levados a conhecimento da Comissão de Valores Mobiliários - CVM, e uma breve diferenciação entre o conflito de interesses no âmbito dos acionistas, dos administradores e dos grupos empresariais, para com os interesses da companhia.

\section{PALAVRAS-CHAVE}

Conflito de Interesses de Acionistas; Conflito de Interesses de administradores; artigo 115 da Lei 6.404/71; Correntes Formal e Substancial; Abuso de Direito de Voto; Parecer de Orientação 35/08; Proibição de Voto. 


\section{EPÍGRAFE}

"Quanto mais aumenta nosso conhecimento, mais evidente fica nossa ignorância".

- J. F. Kennedy. 


\section{ÍNDICE}

INTRODUÇÃO

CAPÍTULO 1

1.Conflito de Acionista $\quad 7$

1.1 - Discussões sobre o conflito de interesses formal ou substancial 7

1.2 - Do conflito de Interesse, do Abuso de Direito de Voto e da Proibição de

Voto

11

CAPÍTULO 2

2. Decisões da CVM 29

2.1 Caso Tele Celular Sul Participações S.A. ou caso TIM 30

2.2 Caso PREVI - SISTEL 33

2.3 Caso AMBEV 35

2.4 Caso TRACTEBEL 38

2.5 Outras considerações 42

CAPÍTULO 3

3. Conflito de Interesses de Administradores 45

3.1. Discussão entre Conflito formal e substancial 49

3.2 O Parecer de Orientação n 35/08 60

CONCLUSÃO 66 
BIBLIOGRAFIA 


\section{INTRODUÇÃO}

Com o avanço da economia brasileira nas últimas décadas, se torna cada vez mais importante o estudo do Direito Empresarial no Brasil. Dentre os aspectos mais importantes, então as formas de organizações das empresas e a preocupação social com proporcionar um ambiente empresarial saudável para empresários e investidores. Não é de hoje, que a forma mais importante de constituição de uma sociedade empresarial, é a Sociedade Anônima. Tipo social regulado pela Lei 6.404/76 ("Lei da S.A.”).

Em sua grande maioria, as sociedades anônimas são compostas por uma pluralidade de acionistas, onde apesar da dinâmica do anonimato, podemos afirmar que há entre os acionistas de uma sociedade anônima, uma comunhão voluntária de interesses, com o propósito de maximizar e otimizar os investimentos realizados, com interesse primário de auferir o maior lucro possível em sua atividade para posterior divisão entre o quadro societário.

A afirmação anterior, por muitas vezes, não se mostra suficiente para retratar a realidade da dinâmica social, visto que, apesar dessa comunhão voluntária entre os acionistas, podemos encontrar na pluralidade de acionistas os mais variados interesses. Muitas vezes, os interesses particulares de um acionista ou de um conjunto de acionistas podem se mostrar contrários ao interesse primário da sociedade.

Podemos, ainda, afirmar que por muitas vezes, o acionista busca utilizar a sociedade para atingir os seus interesses particulares, inobstante o mesmo ser manifestamente contra ao interesse social.

Surge, assim, a questão do conflito de acionistas, que é melhor identificada quando, ao serem demandados a se manifestarem por meio de determinada deliberação em assembleia geral de acionistas, determinado 
acionista se posiciona de maneira contrária ao que se demonstram serem as melhores práticas para a companhia.

Podemos afirmar que a questão do conflito de interesse e do direito de voto nas assembléias dos acionistas interessados não são temas novos. Inúmeros trabalhos têm sido realizados pela doutrina, buscando a melhor maneira de tratar a questão. No desenrolar dessas discussões não faltaram movimentos que pretenderam impedir, o voto do acionista que tivesse eventual conflito de interesse.

Outro fenômeno que foi objeto da atenção do legislador brasileiro, principalmente por meio da edição da Lei da S.A., foi a questão dos conflitos do interesses pessoais dos administradores da companhia, com os interesses da própria companhia e suas ramificações, que poderiam prejudicar a condução dos negócios da companhia.

Diante deste cenário, busca-se apresentar os principais pontos existentes na doutrina dominante e na jurisprudência dos órgãos judiciais e administrativos sobre o tema, apresentando as discussões mais modernas, que ocorrem quando os aplicadores do direito se deparam com conflitos de interesse no âmbito do direito societário. Abordaremos o tema em questão, sem a pretensão de esgotá-lo, tamanha a sua complexidade e divergência verificada na doutrina e julgados sobre questão. 


\section{CAPÍTULO 1}

\section{Conflito de Acionista}

\section{1 - Discussões sobre o conflito de interesses formal ou substancial}

Para iniciarmos a discussão sobre o conflito de interesses formal ou substancial no Brasil, inicialmente, transcrevemos o Artigo 115 da Lei das S.A.:

“Art. 115. O acionista deve exercer o direito a voto no interesse da companhia; considerar-se-á abusivo o voto exercido com o fim de causar dano à companhia ou a outros acionistas, ou de obter, para si ou para outrem, vantagem a que não faz jus e de que resulte, ou possa resultar, prejuízo para a companhia ou para outros acionistas.

$\S 1^{\circ}$ o acionista não poderá votar nas deliberações da assembléia-geral relativas ao laudo de avaliação de bens com que concorrer para a formação do capital social e à aprovação de suas contas como administrador, nem em quaisquer outras que puderem beneficiá-lo de modo particular, ou em que tiver interesse conflitante com o da companhia.

$\S 2^{\circ}$ Se todos os subscritores forem condôminos de bem com que concorreram para a formação do capital social, poderão aprovar o laudo, sem prejuízo da responsabilidade de que trata o $\S 6^{\circ}$ do artigo $8^{\circ}$.

$\S 3^{\circ}$ o acionista responde pelos danos causados pelo exercício abusivo do direito de voto, ainda que seu voto não haja prevalecido.

$\S 4^{\circ}$ A deliberação tomada em decorrência do voto de acionista que tem interesse conflitante com o da companhia é anulável; o acionista responderá pelos danos causados e será obrigado a transferir para a companhia as vantagens que tiver auferido."

No direito brasileiro, a doutrina se divide em três posições principais quanto à interpretação do disposto no artigo supra mencionado. Para a primeira corrente, a lei afirma que o simples conflito de interesses formal seria suficiente para caracterizar a proibição do voto. A segunda posição defende a 
necessidade de ocorrência de conflito substancial ou material de interesses para que se caracterize a proibição do voto do acionista. Por sua vez, a terceira posição defende que deve ser permitido o voto, quando em conformidade com o interesse social mesmo restando a suspeita de possível conflito de interesses. ${ }^{1}$

Para a caracterização do conflito formal de interesses, bastaria a simples existência de interesse conflitante do acionista com o interesse companhia para haver a proibição do voto. Seriam todos os casos nos quais o acionista e a Companhia estivessem contratando. $\mathrm{O}$ acionista estaria impedido de votar, pois mesmo que houvesse benefícios mútuos e proporcionais para ambas as partes, continuaria a haver conflito e não convergência de interesses. Os formalistas entendem que o conflito de interesses se caracterizaria assim, somente pela aparência do negócio, dispensando qualquer análise concernente ao conteúdo da decisão. Assim, mesmo não havendo dano à companhia, a deliberação deveria ser anulada.

Um dos principais doutrinadores que defendem essa linha é o Mestre Modesto Carvalhosa:

"Há proibição legal para o acionista que tem conflito formal de interesses com a sociedade de votar em qualquer sentido, nem que seja conforme o interesse social. A lei de 1976 é clara em proibir que o acionista vote, seja nas hipóteses específicas de conflito de interesses que enuncia, seja residualmente, em qualquer momento no qual, sob outras modalidades, configura-se essa situação. Convém enfatizar que, no caso de conflito de interesses o que se suspende não é o direito de voto, mas seu exercício. Este fica temporariamente suspenso, tendo em vista apenas determinadas matérias sujeitas à deliberação da assembléia geral ${ }^{2 \%}$.

\footnotetext{
${ }^{1}$ Souza, Thelma, Governança corporativa e conflito de interesses nas sociedades anônimas, São Paulo: Escola Paulista da Magistratura, 2003, p. 69.

${ }^{2}$ CARVAlHOSA, Modesto, Comentários à Lei de Sociedades Anônima, $2^{\circ}$ vol., $4^{\text {o }}$ ed. Saraiva, 2009, pg. 465 e 466.
} 
Podemos encontrar o principal fundamento da medida ex ante, a qual sugere o impedimento do voto, na teoria institucionalista do direito pátrio, a qual aduz que o direito a voto, seria um poder concedido ao sócio, exclusivamente no interesse social, conceitualmente entendido como alheio ao seu próprio interesse, considerando que a pessoa jurídica não possui capacidade para manifestar sua vontade, o que ocorre pela atuação das pessoas físicas que a compõem. Nessa concepção, quando ocorre o conflito formal de interesses com a sociedade, o acionista deveria abster-se do direito ao voto, caso de conflito formal de interesses com a sociedade.

É o que afirma a professora Norma Jonssen Parente, na obra "O Direito Empresarial, O acionista em Conflito de Interesses": ${ }^{3}$

"Não há espaço para que o acionista vote, sendo desnecessário- e inútil - apurar posteriormente se tal voto efetivamente privilegiaria o interesse do sócio em detrimento da sociedade. O impedimento é apurado de forma objetiva, a priori”.

Podemos considerar que um dos principais argumentos a favor da corrente do conflito formal de interesses é a própria interpretação literal do texto legal. Segundo esta corrente a lei seria expressa ao vedar o voto do acionista quando das deliberações nas quais existam interesses em conflito com os interesses da sociedade. ${ }^{4}$

Outro argumento aduzido pelos defensores desta teoria é o de que nos casos aonde o interesse do acionista seja evidentemente contrário aos interesses da sociedade, a resolução da questão seria mais fácil sob a ótica dessa teoria.

\footnotetext{
${ }^{3}$ PARENTE, Norma, O Direito Empresarial, O acionista em Conflito de Interesses, Ed. Método, 2005, pg. 330.

${ }^{4}$ Lei 6.404/76, art. 115 e incisos.
} 
Ainda que se admitisse que o acionista pudesse votar em condições de conflito aparente, seria mais simples verificar se o voto convergiu ou não com o interesse da companhia e, em não sendo, buscar a sua anulação. Esta visão foi mais bem definida pelo autor Fran Martins em seus comentários ao artigo 115 da Lei da S.A.:

"Difícil é, às vezes, descobrir quando os interesses da companhia conflitam com os dos acionistas, por se tratar de matéria de fato, entretanto, segundo se verifica na nova Lei, a deliberação tomada em decorrência do voto do acionista que tem interesse conflitante com o da companhia é anulável, respondendo o acionista pelos danos causados sendo obrigado a transferir para companhia as vantagens que tenha auferido." 5

Em contraponto à teoria formal, como dito acima, está a tese material ou substancial do conflito de interesses, apoiada pela maioria da doutrina. O conflito substancial de interesses, ou conflito stricto sensu, de acordo com Nelson Eizirik ${ }^{6}$, ocorre quando o poder de voto é utilizado com desvio de finalidade, para promover interesses incompatíveis do acionista com o interesse social. Os materialistas apóiam-se nessa leitura de conflito. A consequência lógica disso é que se passa a exigir, para tal enquadramento, provas materiais dessa incompatibilidade, o que requer, por sua vez, que se faça uma análise caso a caso, necessariamente a posteriori da tomada da deliberação.

Argumenta-se que nestes casos, a prévia proibição não seria necessária. Porém, na complexa dinâmica do ramo empresarial, seria inocência do

\footnotetext{
${ }^{5}$ MARTINS, Fran, Comentários à Lei das Sociedades Anônimas, $2^{\circ}$ vol., Tomo II, Forense, pg. 84.

${ }^{6}$ EIZIRIK, Nelson. Temas de Direito Societário. $1^{\mathrm{a}}$ ed. Rio de Janeiro: Renovar, 2005. p. 97: "Com efeito, na hipótese de conflito de interesses (art. $115, \S \S 1^{\circ}$ e $4^{\circ}$ da Lei das S.A.) o entendimento dominante com base no direito comparado, é de que a lei não está se reportando a um conflito meramente formal, mas a um conflito substancial, que somente pode ser verificado mediante examedo conteúdo da deliberação.
} 
aplicador do Direito, supor que o acionista que possui interesse diverso ou nocivo a interesse final da companhia, se declararia como tal. Ademais o conflito se apresentaria de forma capciosa, visto que existe uma suposta relação de reciprocidade entre o acionista e a sociedade, fazendo com que aparentemente interesses se pareçam convergentes e não conflitantes.

Para os defensores dessa segunda corrente, não haveria necessidade de que o voto do acionista causasse prejuízo direto e imediato para a sociedade para que o mesmo seja reprimido. Bastaria o desvio da finalidade do voto, para um fim diverso do interesse social, que per si, seria prejudicial à boa reputação da sociedade.

Este entendimento baseia-se, ainda, no fato de o artigo 115 da Lei das S.A., prever em mais de uma oportunidade que o voto conflitado seja o voto orientado não pelo interesse geral da sociedade e independendo da ocorrência de dano efetivo. Assim sendo, não seria razoável exigir que seja demonstrado um dano superveniente para justificar a proibição ex ante deste tipo de voto, até porque, o retorno ao status quo ante normalmente requer um grande esforço, em muitos casos sendo impossível. Portanto, a alternativa mais plausível seria a opção pela via da prevenção, diante da remota possibilidade de um dano ou de um dano eminente.

Por questão de lógica argumentativa, passaremos à análise da terceira corrente nas próximas páginas.

\section{2 - Do conflito de Interesse, do Abuso de Direito de Voto e da Proibição de Voto.}


Merece destaque o fato de o ordenamento brasileiro fazer uma distinção entre o conflito de interesses e o exercício abusivo do direito de voto, visto que os casos de proibição do direito de voto estão expressamente previstos na Lei.

Este último poderá ocorrer inclusive nas hipóteses em que não exista impedimento para que o acionista exerça o seu direito ao voto nas quais o acionista não esta impedido de votar. Por não estar proibido de votar, o acionista estaria livre para registrar seu voto e o mesmo seria válido. Entretanto caracterizada abusividade do seu exercício, com dolo específico de causar algum dano, seja aos acionistas, seja à sociedade, poderia haver responsabilização do acionista infrator por perdas e danos.

A teoria materialista encontra no Direito Comparado outro de seus principais argumentos. Ocorre que no continente europeu existe a diferenciação entre os institutos jurídicos da proibição de voto e do conflito de interesses. Essa distinção surgiu primeiramente na Alemanha e, posteriormente, na Itália, país cuja legislação, vale lembrar, serviu de inspiração para a edição da Lei das S.A.

Vejamos o que dizem Marcelo Lamy Rego e ErasmoValladão Azevedo e Novaes França sobre o tema:

\footnotetext{
"As três primeiras hipóteses são hipótese às quais a lei dá tratamento semelhante ao divieto de voto, tendo o legislador prescrito situações formais em que o acionista não pode exercer o voto. (...) O conflito de interesses na lei brasileira, assim como na doutrinas alemã e italiana, é hipótese distinta das demais, apesar de estar relacionada juntamente com as proibições objetivas de voto. (...) Entendemos que o conflito de interesses é caso em que a tutela do interesse social se dá a posteriori, com a análise do caso concreto." 7
}

\footnotetext{
${ }^{7}$ REGO, Marcelo Lamy. Direito das Companhias. $1^{\text {a }}$ ed. Rio de Janeiro: Forense, 2009. v. I, p. 411.
} 
Não se pode, contudo, deixar de mencionar a crítica dos seguidores da tese formalista a essa classificação. Alegam que essa interpretação é falha, pois se estaria admitindo a heterogeneidade dos comandos do parágrafo $1^{\circ}$ do art. 115. Veja-se abaixo o que disse, nesse sentido, a diretora Maria Helena Santana face ao Processo Administrativo Nº RJ 2009-13179:

\footnotetext{
"A outra fragilidade da visão vinculada ao chamado conflito substancial diz respeito à incongruência que introduz na interpretação do disposto no $\S 1^{\circ}$ do art. 115 . Isto porque, a se adotar essa posição, seria necessário admitir a heterogeneidade do comando contido nesse preceito legal, que teria, por assim dizer, enunciado sucessivamente três hipóteses de proibição de voto - laudo de avaliação dos bens com que concorrer o acionista para a formação do capital social, aprovação das contas do acionista como administrador, qualquer outra que possa beneficiar o acionista de modo particular - para, ao final, introduzir regra de natureza totalmente diversa, pela qual não mais se impediria o acionista de votar, mas, ao contrário, estaria estabelecida a sanção posterior ao voto exercido em contradição com o interesse da companhia."
}

Em suma, o legislador dividiu as espécies de remédios jurídicos aplicáveis às diferentes hipóteses do parágrafo $1^{\circ}$ do artigo $115 \mathrm{em}$ duas categorias: (i) nulidade para os três primeiros casos; e (ii) anulabilidade, responsabilidade por perdas e danos e transferência de vantagens para a companhia na última hipótese. Fez isto, justamente por saber que o voto do acionista em conflito aparente poderia ser proferido em favor dos interesses da companhia, descartando a necessidade de uma nulidade imperativa.

Por sua vez, no caso de conflito de interesse, o acionista continuaria titular de seu direito de voto, e não havendo a suspensão de seu direito lato sensu de voto. O mesmo estaria apenas impedido ex ante de votar em determinadas matérias, restringindo apenas o exercício do direito ao voto que possui. Caso existam outras matérias em pauta na mesma assembleia, o acionista estaria livre para votar, resguardando-se, ainda, o direito de 
participação na em qualquer assembleia, podendo inclusive impugnar a deliberação, caso assim entenda necessário.

Pode, inclusive, votar em outras matérias da mesma assembléia, para quais não haja impedimento. Mesmo nas matérias que é impedido de votar, o votante tem o direito de participar da assembléia geral e de impugnar a deliberação. A lei só veda o exercício do voto, mas não dos demais direitos. ${ }^{8}$

Conforme previsto no Parágrafo $4^{\circ}$ do Artigo 115 da Lei das S.A., a deliberação que foi aprovada por voto conflitado é apenas anulável e a ação para anular a deliberação possui prazo prescricional de dois anos, conforme inteligência do Artigo 286 da Lei das S.A.:

\footnotetext{
“Art. 286. A ação para anular as deliberações tomadas em assembléia-geral ou especial, irregularmente convocada ou instalada, violadoras da lei ou do estatuto, ou eivadas de erro, dolo, fraude ou simulação, prescreve em 2 (dois) anos, contados da deliberação."
}

Todavia, na visão dos substancialistas, a deliberação só seria objeto de ação anulatória se o computo dos votos nulos forem decisivos para o resultado final daquela deliberação. Caso não tenham relevância para o resultado final não há o que se falar em reforma da decisão. $\mathrm{O}$ voto dos impedidos seriam nulos mesmo no caso de a deliberação não ser anulável, visto que não poderiam fundamentar voto vencido e nem ao menos gerar qualquer tipo de efeitos.

Para melhor analisar a questão de conflito de interesses, outra questão que merece nossa atenção, diz respeito à definição do que seria "benefício particular" e "vantagem indevida". Por algumas vezes já se manifestou o

\footnotetext{
${ }^{8}$ RIBEIRO, Renato, Direito de Voto nas Sociedades Anônimas, Quartier Latim, 2009.
} 
colegiado da CVM, como podemos verificar no voto proferido pelo relator do Processo Administrativo CVM RJ2006/6785, Pedro Oliva Souza:

"De uma maneira geral, "interesse particular" vem sendo entendido como um benefício a determinado acionista, nesta qualidade (ou seja, não se trata de outros benefícios que um acionista pode receber como contraparte em contrato com a companhia ou como administrador dela ou por qualquer outra forma que não em decorrência de sua qualidade como acionista)(...)"

A vantagem indevida seria o exercício do voto para obtenção de alguma espécie de vantagem, seja ela política ou patrimonial, a qual não alcançaria em condições normais. Por outro lado, o benefício particular é, por definição, autorizado por lei. Todavia, havendo evidencias de um potencial conflito de interesses que beneficiaria o acionista, o mesmo deveria estar impedido de votar.

Continuando a análise da questão, cumpre inicialmente transcrever trecho do Parecer de Orientação CVM no 34 de 18.08.2006:

“(...) A constatação do impedimento do voto não envolve um julgamento sobre a licitude da deliberação a ser tomada. O acionista potencialmente favorecido estará impedido de votar mesmo que se trate, como se espera, de deliberar sobre benefícios perfeitamente lícitos, e que possam coincidir com o interesse da companhia. O impedimento de voto, portanto, se dá pela especificidade do beneficio, pela particularidade de seus efeitos em relação a um acionista, comparado aos demais. E mesmo em tais casos, se falhar a proibição cautelar de voto, e o acionista impedido de votar, a deliberação somente será anulável se o voto do acionista potencialmente beneficiado tiver sido determinante para a formação do quorum ou da maioria assemblear." 9

\footnotetext{
${ }^{9}$ Disponível no site da CVM. Parecer de Orientação CVM nº34/2006.
} 
Em análise livre, podemos entender que o impedimento de voto em casos de beneficio particular que ocorrem quando o voto é proferido no âmbito de operações de incorporação de ações as quais sejam indexados valores diferentes para ações emitidas por uma das companhias envolvidas na operação, variando em relação a sua titularidade, classe ou espécie. Vejamos de que forma o colegiado da CVM, por meio de seu Diretor Relator Pedro Oliva Souza, em seu voto no PA CVM RJ 2006/6785, sobre a aplicação do Parecer de Orientação mencionado:

"O PO 34/2006 foi editado justamente, respeitando esse entendimento que vem sendo repetido através dos tempos pela doutrina e legislação brasileira: se uma deliberação assemblear pode atribuir a um ou mais cotistas um beneficio usufruível na qualidade de acionista (usualmente maior participação no capital social ou no direito ao recebimento de dividendos), os beneficiados não participam da votação. $O$ PO 34/2006 trata diretamente de reestruturações monetárias como a que a companhia pretende implementar, na qual o beneficio particular adviria de atribuição de acionista controlador, de uma participação maior no capital da sociedade resultante (ou remanescente) da Reestruturação Societária do que o porcentual entregue por esse acionista. Também o acionista ordinário não controlador teria um beneficio particular da mesma natureza, mais em um percentual inferior ao conferido ao acionista controlador. O 'custo' desses benefícios seria suportado pelos acionistas preferenciais que receberiam uma participação no capital social da sociedade resultante inferior à que ele teria entregue. Tudo isso sem que um critério objetivo conseguisse conferir valores diferentes à participação de cada um desses acionistas e, portanto, transformar o que seria 'beneficio particular' em atribuição correta de valor. Assim, para saber se acionistas titulares de ações ordinárias e preferenciais poderão votar na Assembléia e preciso saber se o 'beneficio particular' está sendo a ele atribuído ou não. Existirão casos em que essa resposta e afirmativa outros em que a resposta é negativa: se o 'beneficio' recebido em decorrência da titularidade do conjunto de ações ordinárias for inferior (ou igual) ao 'custo' incorrido em decorrência da titularidade do conjunto de suas ações preferenciais, o acionista não terá 'beneficio particular', pois terá suportado, ele próprio o 'custo' de seu 'beneficio'. Caso, no entanto, o 'benefício' recebido seja superior ao 'custo'(e, 
portanto ele venha a possuir, após a Reestruturação Societária parcela maior do capital social da companhia resultante) tem-se que o acionista não poderá votar, pois esta recebendo um 'beneficio particular' em decorrência da deliberação assemblear. Em caso de beneficio particular o acionista esta impedido do voto."

Outras interpretações sobre o tema merecem atenção, como a trazida pelo Mestre José Luiz Bulhões Pedreira coautor do anteprojeto que se converteu na Lei 6.404/76:

"Interesse conflitante significa interesse oposto, contrário, incompatível ou colidente. Não é apenas interesse diferente ou distinto, que pode ser, inclusive, coincidente com o da companhia, ou complementar a este: é valido o voto proferido pelo acionista no interesse da companhia, ainda que na deliberação tenha outro interesse próprio, distinto do da companhia, desde que não seja com este conflitante." 11

Endossando a opinião acima, segue a lição de Erasmo Valladão Azevedo e Novaes e França:

“(...) Entendemos, dessa forma, que ao fazer referência a 'interesses conflitante com o da companhia', no $\S 1^{\circ}$, do art. 115 , a lei não esta se reportando a um conflito meramente formal, mais sim a um conflito substancial, que só pode ser verificado mediante o exame do conteúdo da deliberação." 12

No mesmo sentido, os ilustres juristas Drs. Jose Bulhões Pedreira e Alfredo Lamy Filho, respectivamente, quando da emissão de seus pareceres:

"Se o acionista tem interesse conflitante com o da companhia mas vota efetivamente no interesse desta, e não em outro interesse extra-social, o exercício do voto é regular e valido.(...)

\footnotetext{
${ }^{10}$ SOUZA, Pedro Oliva, Diretor Relator da CVM em seu voto no Processo Administrativo CVM RJ2006/6785.

${ }^{11}$ Revista de Direito Mercantil, RDM n ${ }^{\circ}$ 128, p.230 e 231.

${ }^{12}$ FRANÇA, Erasmo Valladão Azevedo e Novaes, Conflito de Interesses nas Assembléias de S.A, p.97.
} 
Esse regime da lei explica-se porque a existência do conflito de interesses potencial autoriza a suspeita, mas não a certeza, da violação da norma legal que prescreve ao acionista o dever de votar no interesse da companhia, e não em interesse extra-social oposto ao da companhia. $\mathrm{O}$ ato ilícito consiste em votar em interesse contrario ao da companhia, e não em votar tendo um interesse extra-oficial." 13

\title{
Alfredo Lamy Fillho:
}

"Não nos parece, por todo o exposto, subsistam duvidas de que o $1^{\circ}$ do art.. 115 - até por ser § que explica hipóteses do caput - há que ser entendido e aplicado no sentido de que ' o interesse conflitante', a ser examinado e caracterizado em cada caso, e não no mero aspecto formal (como num contrato bilateral) supõe o exame da causa ('com o fim de causar dano à companhia ou a outros acionistas') ou de 'obter para si ou para outrem vantagem a que não faz jus." 14

Sobre os mais adotados entendimentos em relação à materia, se mostra relevante a posição adotada Diretor Relator Luiz Antonio Sampaio Campos, no Inquérito Administrativo CVM no RJ2002/1153:

\begin{abstract}
"Em minha opinião, quando há referencia genérica ${ }^{15}$. Que me parece ser o melhor sistema, o tratamento deve ser aquela agasalhado pela remansosa doutrina e jurisprudência (i.e substancial, colidente, estridente, não formal, etc.), pois dada a subjetividade da avaliação e a largueza do conceito, parece-me impensável que a avaliação primeira de conflito de interesses fosse de outra pessoa que não o acionista interessado, pois só ele poderá, antes mesmo de proferir o voto, avaliar se esta em conflito de interesses ou não com a companhia na deliberação, inclusive porque somente ele sabe o teor do voto que proferirá. Ate mesmo em razão de o conflito
\end{abstract}

\footnotetext{
${ }^{13}$ CAMPOS, Luiz Antonio de Sampaio, Diretor Relator, p. 282 e 283 do voto do Diretor Relator no IA CVM n ${ }^{\circ}$ RJ 2002/1153.

${ }^{14}$ Revista de Direito Mercantil, RDM no 128, p. 234, voto do Diretor Relator Luiz Antonio Sampaio Campos, IA CVM n ${ }^{\circ}$ RJ2002/1153.

${ }^{15}$ Outra forma de se compreender o conflito substancial. É o oposto da pontual, que é a proibição específica, taxativa, enumerada na legislação.
} 
poder resultar de uma situação que nem transpareça formalmente, mas onde ainda assim exista o conflito." 16

Em uma das esparsas decisões proferidas por tribunais sobre a questão, temos que destacar como relevante, o voto do Ministro Aldir Passarinho Junior no âmbito do Recurso Especial 131.300 - RS:

"Não existindo um conflito de interesse estritamente colidente de um acionista em relação à própria empresa, não há razão para se afastar da votação o acionista, no caso majoritário, ficando muito difícil se gerir uma sociedade, porque a todo o momento, se poderia interpretar que tal ou qual atitude desde acionista estaria ou não colidindo com o interesse daquela, quando é ele ter a maioria do capita,l quem toma as decisões." 17

Para Lacerda Teixeira e Tavares Guerreiro $^{18}$ a lei não comporta interpretação para a corrente doutrinaria que defende o conflito formal de interesses. Isso porque a larga previsão do $\S 1^{\circ}$ do art. 115 da Lei das S.A., falam apenas do tema conexo ao caso concreto. ${ }^{19}$

Verificamos então que a doutrina divide em duas categorias, as hipóteses previstas em Lei. A primeira recebe a denominação de objetiva, e acarreta na proibição do direito de voto. A segunda, denominada subjetiva, considera que o acionista votar sempre observando o princípio da boa-fé e em direção dos interesses da companhia, ou seja, presume-se a boa-fé.

\footnotetext{
${ }^{16}$ CAMPOS, Luiz Antonio de Sampaio, Diretor Relator, voto do Diretor Relator no IA CVM n ${ }^{\circ} \mathrm{RJ}$ 2002/1153.

${ }^{17}$ JUNIOR, Aldir Passarinho, Ministro, no Recurso Especial 131.300-RS.

${ }^{18}$ TEIXERA, Lacerda e GUERREIRO, Tavares, in REGO, Marcelo Lamy, in O Direito das Companhias, $1^{\circ}$ vol., $1^{\circ}$ ed., ed. Forense, 2009, p. 422 e 423.

${ }^{19}$ REGO, Marcelo Lamy, in O Direito das Companhias, $1^{\circ}$ vol., $1^{\circ}$ ed., ed. Forense, 2009, p. 422 e 423.
} 
Defende-se que não haveria prejuízo à Companhia, uma vez que é possível a anulação da deliberação conflitada, nos termos do Artigo115 $\S 4^{\circ}$ da Lei das S.A.. Por outro lado, afirma-se que, realizando uma interpretação sistemática do texto legal, que seria possível a manifestação de voto em deliberação mesmo quando exista voto conflitado, pois a Lei das S.A., em seu artigo $117, \S 1^{\circ}$, alínea $\mathrm{f}$, considera exercício abusivo de poder, apenas a contratação pela companhia, com sociedades nas quais o administrador tenha interesse, em condições não equitativas. Portanto, em uma interpretação contrario sensu, negócios em condições equitativas de mercado seriam legais. $^{20}$

O simples fato de o acionista encontrar-se na situação descrita impede o voto. O conflito de interesses, no entanto, não e matéria que possibilite préjulgamento do voto, tanto que na própria, Lei das S.A admite-se, por exemplo, o contrato da sociedade com o acionista (ou mesmo com o administrador), nos art. $117, \S 1^{\circ}$, alínea "e", art. $156 \S 1^{\circ}$. São casos em que acionista ou administrador e companhia estão em posições contrapostas (e, normalmente

\footnotetext{
${ }^{20}$ Art. 117. O acionista controlador responde pelos danos causados por atos praticados com abuso de poder.
}

$\S 1^{\circ}$ São modalidades de exercício abusivo de poder:

$(\ldots)$

f) contratar com a companhia, diretamente ou através de outrem, ou de sociedade na qual tenha interesse, em condições de favorecimento ou não equitativas;

$(\ldots)$

$\S 2^{\circ}$ No caso da alínea e do $\S 1^{\circ}$, o administrador ou fiscal que praticar o ato ilegal responde solidariamente com o acionista controlador.

$\S 3^{\circ} \mathrm{O}$ acionista controlador que exerce cargo de administrador ou fiscal tem também os deveres e responsabilidades próprios do cargo. 
em conflito), e nem por isso estão impedidos previamente de agir. São vigiados de perto, com seu direito circunscrito por normas dispositivas que, uma vez quebradas, permitem a anulação do negocio e a cobrança dos danos havidos. Essa é também a regra que vale para o conflito de interesses no exercício do direito do voto.

Pode-se dizer mais. Nas situações que aparentam conflito de interesses nem sempre o são, como por exemplo, seria o caso dos contratos bilaterais, onde as partes têm interesses opostos, porém, complementares, como explicado por José Luiz Bulhões Pedreira, em seu parecer já citado:

\begin{abstract}
"A improcedência da interpretação que caracteriza o conflito de interesses a partir de definições genéricas baseadas em aspectos formais, como tipos de negócios jurídicos, é demonstrada pelos exemplos de conclusões absurdas ou desarrazoadas a que conduz, como a que considera que há necessariamente conflito de interesses quando a companhia e o acionista são partes de negócios bilaterais comutativos, como, por exemplo, a compra e venda. O vendedor e o comprador têm interesses distintos: o primeiro, de vender a coisa para realizar o preço, e o segundo, de adquirir a propriedade da coisa mediante pagamento do preço. São partes opostas no contrato, mas esses interesses não são conflitantes, e sim complementares: cada um somente pode satisfazer seu interesse se o outro satisfizer o seu." 21
\end{abstract}

\title{
Marcelo Lamy Rego corrobora com o entendimento supracitado:
}

“(...) Interesses complementares, não excludentes, não são interesses em conflito. A existência do conflito pressupõe que um interesse deva ser sacrificado para que o outro prospere. Nada impede que o acionista sacrifique seu interesse pessoal, estranho à comunhão, em prol do interesse social - que está obrigado por lei a satisfazer. A presunção deve ser a de que o acionista vá agir de acordo com a lei e não o contrário, com o bom senso pode nos fazer crer em algumas situações",22.

\footnotetext{
${ }^{21}$ Parecer de Jose Luiz Bulhões

${ }^{22}$ REGO, Marcelo Lamy, Direito das Companhias, $1^{\circ}$ vol., $1^{\circ}$ ed. Forense, 2009, p.425.
} 
Diversos são os argumentos utilizados para defesa do conflito substancial. Um deles seria a avaliação das conseqüências da interpretação puramente formal ou do duplo interesse, alegando que levaria à situações de muita perplexidade e dificuldade. Situações por exemplo, em que poderiam os acionistas da companhia e a diversidade de papéis e interesses que pode ter o acionista, qualquer que ele seja, controlador ou minoritário. Alfredo Lamy Filho e Jose Luiz Bulhões Pedreira também falaram da hipótese:

\begin{abstract}
"A pessoa que o acionista desempenha, simultaneamente, diversos outros papéis sociais, nos quais busca fins e tem interesses que são estranhos aos da companhia, ou com eles conflitam. Pode, por exemplo, ser administrador ou empregado da companhia, fornecedor de bens ou serviços adquiridos pela companhia ou comprador dos seus produtos, empresário de empresa concorrente, parente de algum de seus diretores ou seu acionista controlador. Ao prescrever o exercício do direito de voto no interesse da companhia, a lei proíbe ao acionista colocar a serviço de qualquer outro papel que ocupe um poder jurídico que é conferido para o desempenho da função do membro da Assembléia-Geral. A caracterização do direito de voto como "direito-função" e a distinção entre os atos do acionista enquanto sócio e como pessoa são outros modos de exprimir o mesmo princípio."23
\end{abstract}

Os autores também destacam também, a diferença entre o que seria benefício particular e o interesse conflitante. Na visão dos doutrinadores desta corrente o beneficio particular se configura na própria condição de acionista, baseado na lei, é uma vantagem lícita que impede o acionista de votar quando esta na posição onde estaria se concedendo um prêmio, mas, por exemplo, na hipótese da fundação da sociedade é natural que se atribua vantagem ao acionista controlador. Então ela pode ser ilícita porque como é uma vantagem que não se pode medir, por exemplo, aposentadoria, não se mede com antecedência, seria uma situação onde o acionista controlador estaria julgando seus próprios serviços para constituição da companhia, em causa própria.

\footnotetext{
${ }^{23}$ Revista de Direito Mercantil no $128, \ldots$, p.238
} 
O beneficio particular, portanto, é vantagem lícita, estando exemplificada no art. $84, \S 6^{\circ}$ da Lei das S.A ${ }^{24}$, que cuida do prospecto que deve ser apresentado na formação da companhia, permitindo as vantagens particulares que os fundadores terão e os outros acionistas não.

Pode-se citar também, quatro exemplos de artigos da Lei das S.A que estabelecem princípios gerais em que, na visão dos doutrinadores, se comprova que o legislador não visou combater o interesse formalmente conflitante mais sim o substancial.

O autor Erasmo Valladão cita primeiramente o art.117, §1 $1^{\circ}$, letra "f" ${ }^{25}$, onde ele afirma que no artigo citado, o exercício abusivo de poder no caso de contratar com a companhia apenas se dá nas condições de favorecimento ou não equitativas, caso contrário o controlador pode contratar com a companhia, alertando ainda, que o controlador sequer necessita de autorização da assembléia para contratar. Argumenta, portanto, que se o legislador quisesse combater o conflito formal nunca teria permitido que o controlador contratasse, pois este seria o exemplo clássico conflito de formal.

Outro exemplo seria o art. $156, \S 1^{\circ}$ e $\S 2^{\text {o26 }}$ da mesma lei, veda que o administrador aja de forma específica, permitindo que o administrador contrate

\footnotetext{
${ }^{24}$ Artigo da Lei 6.404/1976, Art. 84. O prospecto deverá mencionar, com precisão e clareza, as bases da companhia e os motivos que justifiquem a expectativa de bom êxito do empreendimento, e em especial:

VI - as vantagens particulares, a que terão direito os fundadores ou terceiros, e o dispositivo do projeto do estatuto que as regula;

${ }^{25}$ Lei 6.404/1976, Art. 117. O acionista controlador responde pelos danos causados por atos praticados com abuso de poder. $\S 1^{\circ}$ São modalidades de exercício abusivo de poder: f) contratar com a companhia, diretamente ou através de outrem, ou de sociedade na qual tenha interesse, em condições de favorecimento ou não equitativas; (grifei)
}

26 Lei 6.404/1976, Art. 156. É vedado ao administrador intervir em qualquer operação social em que tiver interesse conflitante com o da companhia, bem como na deliberação que a respeito tomarem os 
com a companhia salvo se em condições razoáveis, e o $\S 2^{\circ}$, garante a anulação da operação, apenas se houver infração ao $\S 1^{\circ}$, o que confirma que o banido não seria o conflito formal e sim o substancial.

$\mathrm{O}$ art. $245^{27}$ da lei do anonimato, também demonstra tal princípio, no sentido em que afirma que os administradores não podem em prejuízo da companhia favorecer sociedade coligada, controladora ou controlada, salvo se mediante pagamento compensatório adequado, portanto, a contrario sensu os administradores grupais podem desfavorecer controladas, controladoras ou coligadas, desde que, haja um pagamento compensatório adequado.

Não existem duas maiorias diferentes, a maioria da controladora é a mesma maioria que existe na controlada, então os legisladores estabeleceram uma disciplina para garantir os minoritários. $\mathrm{O}$ art. $264, \S 3^{\circ}{ }^{28}$, dispõe que o

demais administradores, cumprindo-lhe cientificá-los do seu impedimento e fazer consignar, em ata de reunião do conselho de administração ou da diretoria, a natureza e extensão do seu interesse.

$\S 1^{\circ}$ Ainda que observado o disposto neste artigo, o administrador somente pode contratar com a companhia em condições razoáveis ou eqüitativas, idênticas às que prevalecem no mercado ou em que a companhia contrataria com terceiros.(grifei)

$\S 2^{\circ} \mathrm{O}$ negócio contratado com infração do disposto no $\S 1^{\circ}$ é anulável, e o administrador interessado será obrigado a transferir para a companhia as vantagens que dele tiver auferido.

${ }^{27}$ Lei 6.404/1976, Art. 245. Os administradores não podem, em prejuízo da companhia, favorecer sociedade coligada, controladora ou controlada, cumprindo-lhes zelar para que as operações entre as sociedades, se houver, observem condições estritamente comutativas, ou com pagamento compensatório adequado; e respondem perante a companhia pelas perdas e danos resultantes de atos praticados com infração ao disposto neste artigo.

${ }^{28}$ Lei 6.404/1976, Art. 264. Na incorporação, pela controladora, de companhia controlada, a justificação, apresentada à assembléia-geral da controlada, deverá conter, além das informações previstas nos arts. 224 e 225, o cálculo das relações de substituição das ações dos acionistas não controladores da controlada com base no valor do patrimônio líquido das ações da controladora e da controlada, avaliados os dois patrimônios segundo os mesmos critérios e na mesma data, a preços de mercado, ou com base em outro critério aceito pela Comissão de Valores Mobiliários, no caso de companhias abertas.

$\S 3^{\circ}$ Se as relações de substituição das ações dos acionistas não controladores, previstas no protocolo da incorporação, forem menos vantajosas que as resultantes da comparação prevista neste artigo, os acionistas dissidentes da deliberação da assembléia-geral da controlada que aprovar a operação, observado o disposto nos arts. 137, II, e 230, poderão optar entre o valor de reembolso fixado nos termos do art. 45 e o valor do patrimônio líquido a preços de mercado 
acionista minoritário pode exercer o direito de recesso, em algumas condições, então, na visão da corrente defensora, o controlador pode votar, senão não se explicaria o direito de recesso do acionista minoritário, o que comprova também que o legislador estava voltado para o combate do interesse substancial.

Quanto à questão da validade do voto em conflito de interesses, os doutrinadores desta corrente afirmam que, salvo quando o acionista estiver em conflito formal (sendo este interpretado como os conflitos previstos em lei), o voto é anulável e não nulo. Defendem que a anulação do voto em conflito depende de uma análise do conteúdo do mesmo. Tendo o acionista sacrificado o interesse coletivo em prol de interesse individual, seu voto deve ser anulado. Nada obstante, tendo o acionista cumprido com a obrigação primária de votar no interesse da sociedade, seu voto é valido. E justamente por não se poder prever, de antemão, o comportamento do acionista, que o conflito de interesses deve ser analisado caso a caso - e após o exercício do voto pelo acionista.

Nessa linha, cumpre mencionar o pensamento do autor Erasmo Valladão:

\footnotetext{
"Se acionista vota em impedimento o voto é nulo, claro, porque há proibição legal, já a deliberação é anulável, porque se o voto for determinante pra maioria com o princípio da maioria cogente, cai a maioria, o que é viciado por erro, dolo, coação é o voto e nunca a deliberação, então somente se o voto for determinante para formação da maioria na deliberação, senão pode-se anular o voto. Há o caso de o votante ter interesse em anular seu próprio voto, porque ele está submetido a perdas e danos, ainda que seu voto não tenha prevalecido, ele poderá ser responsabilizado, então terá interesse em declarar a nulidade de seu voto." ${ }^{29}$
}

\footnotetext{
${ }^{29}$ FRANÇA, Erasmo Valladão e Novaes, Seminário de Direito Empresarial ocorrido na PUC-RIO, Conflito de interesses no exercício de voto, 21.10.2010.
} 
Por fim, do ponto de vista prático, alertam para a possibilidade da falta de quórum, diante de eventual impedimento do controlador de votar e ausência dos minoritários ausentes. Portanto, se deixar nas mãos do minoritário uma operação que pode beneficiar a companhia e esta for vetada pelos mesmos, não tem volta, e não adiantaria anular o voto do minoritário, porque o controlador não votou, e a operação não se realiza. Se permitindo que o acionista controlador vote, pode-se ao menos anular a deliberação no caso de abuso de poder, ou seja, tem conserto. Assim, afirmam a melhor solução seria apurar posteriormente se o voto do controlador foi contrario ou não do interesse social e, se for o caso, requerer a anulação da decisão.

O autor Erasmo Valladão em defesa do conflito material em debate no seminário já citado, afirma que tanto os majoritários quanto minoritários podem abusar do seu direito de voto quando colocados em situações de decisão. Tanto que os dois estão sujeitos à punição. E afirma que a lei deveria ter estabelecido a inversão do ônus da prova, já que se considera sustentável no caso de conflito formal que o acionista não vote, ele tem o ônus de provar que seu voto não será conflitante com o da companhia.

Apesar dos precedentes da CVM acima citados, a doutrina majoritária é no sentido de que a natureza do conflito de interesses é substancial, ou seja, como questão de fato, ele deve ser analisado, casuisticamente, após a prolação do voto.

A terceira corrente consiste na defesa de uma espécie de posição intermediária, pela qual o conflito é identificado por meio de um critério formal, mais a proibição do voto pode ser elidida pela prova de que tal voto estará alinhado com o interesse social. É o que ensina, por exemplo, Thelma Mesquita de Garcia e Souza: 
"Porém, entendemos que o critério formal estabelecido na quarta hipótese do parágrafo $1^{\circ}$ do art. 115 , embora proíba o voto conflitante, presumindo-se o conflito quando o acionista contrata com a sociedade, não autoriza uma presunção absoluta. Daí concluirmos que se trata de presunção juris tantum, comportando, por isso, prova em contrário, que incumbe àquele que contra o qual se estabeleceu a presunção, e que apresentará à assembléia argumentos aptos a demonstrar que seu voto se norteará pelo interesse da companhia.",30

Outros doutrinadores que defendem a segunda corrente anteriormente apresentada, indo além, defendem que esta prova sequer precisaria ser apresentada em assembléia, mas apenas no âmbito de processo judicial eventualmente instaurado para anular o voto conflitante proferido, o que, em outras palavras, representaria uma inversão do ônus probatório: em vez de acionista demonstrar o prejuízo ao interesse social, o acionista que tenha dado o voto é quem deveria comprovar que o fez de acordo com o interesse da companhia.

Evidentemente, exigir que se instaure uma contenda judicial para demonstrar que o interesse social foi atingido, no mínimo, fere o bom senso. O alinhamento com interesse social é condição de validade para o voto, como antes já expusemos, de sorte que não podem pairar duvidas sobre sua existência, quanto mais se tais dúvidas dependerem de um processo dispendioso e lento para serem dirimidas. Nesse sentido, a alternativa de apresentação de provas à assembléia geral é muito mais razoável, mas, se pensarmos a fundo, tampouco resolve a questão. Quem ira julgar se as provas produzidas pelos acionistas são suficientes? Se esta tarefa couber aos demais acionistas, então, a rigor, os resultados práticos são os mesmo da posição formalista, em que é necessário o convencimento dos demais sócios para aprovação da deliberação.

\footnotetext{
${ }^{30}$ SOUZA, Thelma, Governança corporativa e o conflito de interesses nas sociedades anônimas, São Paulo: Escola Paulista de Magistratura, 2003.
} 
Por outro lado, se ao próprio acionista em conflito for dada a possibilidade de avaliar a quantidade e qualidade das provas por ele levadas à assembléia, surge ai um novo conflito de interesses. Nesse caso, a questão estaria apenas sendo deslocada da deliberação originalmente pretendida para a decisão acerca da suficiência das provas de que autorizariam o voto do acionista conflitante. 


\section{CAPÍTULO 2}

\section{Decisões da CVM}

Quando falamos de da Jurisprudência brasileira sobre a questão do conflito de interesses no âmbito das relações entre acionistas, devemos quase que exclusivamente recorrer à Comissão de Valores Mobiliários - CVM.

A Lei que criou a CVM, Lei 6385/76 e a Lei das S.A. disciplinam o funcionamento do mercado de valores mobiliários e a atuação de seus protagonistas, assim classificados, as companhias abertas, os intermediários financeiros e os investidores, além de outros cuja atividade gira em torno desse universo principal.

A Lei atribui à CVM competência para apurar, julgar e punir irregularidades eventualmente cometidas no mercado. O Colegiado tem poderes para julgar e punir o faltoso. As penalidades que a CVM pode atribuir vão desde a simples advertência até a inabilitação para o exercício de atividades no mercado, passando pelas multas pecuniárias.

Em função das atribuições legais da CVM, não são muitos os casos de conflitos de interesses em sociedades anônimas levados aos tribunais brasileiros. Em regra, a matéria se esgota no plano administrativo, em que a CVM, no âmbito de sua atuação sancionadora, já enfrentou o tema em algumas oportunidades, dentre as quais podemos destacar o caso Tele Celular Sul Participações S.A. ou caso TIM, o caso PREVI e SISTEL, o caso AMBEV e o mais famoso, o caso TRACTEBEL.

Apesar de ter encampado a tese do conflito formal no Inquérito administrativo acima, a CVM ao longo da última década, proferiu decisões que podem parecer contraditórias ao se manifestar sobre a questão. A mudança no 
entendimento do Colegiado da CVM acabou por coincidir com as mudanças ocorridas em sua composição, portanto agora, podemos afirmar que as decisões proferidas em processos administrativos têm sido fundamentadas em função da teoria do conflito substancial.

Passamos nas próximas linhas, a uma análise mais aprofundada de cada um dos casos que consideramos mais importantes, e outros que passaram pela análise do colegiado da CVM.

\subsection{Caso Tele Celular Sul Participações S.A. ou caso TIM}

O Inquérito Administrativo CVM TA/RJ2001/4977, julgado em 19.12.2001, que tratou principalmente da aprovação pela Assembléia Geral Extraordinária da CTMR Celular S.A., do pagamento de 1\% de sua receita liquida à Telecom Itália Móbile, sociedade ligada ao grupo econômico do controlador indireto da CTMR Celular S.A., a titulo de royalties pelo uso da marca "TIM". Tal deliberação foi tomada por unanimidade dos acionistas presentes, inclusive com voto do controlador direto da CTMR Celular S.A., a Tele Celular Sul Participações S.A. Neste caso, a CVM adotou a tese de conflito formal, e por maioria dos seus diretores, decidiu punir os indiciados.

O voto vencedor foi liderado pela diretora relatora Norma Jonssen Parente, que defendeu que a acionista controladora Tele Celular Sul Participações S.A. deveria ter se considerado impedida de votar em assunto em que tinha interesse conflitante ou que a beneficiava de modo particular. Alegou não ser sequer necessária a verificação de que os interesses da Tele Celular Sul Participações S.A. estavam contrapostos aos da CTMR Celular S.A: 
lados, razão pela qual deveria abster-se de votar, independentemente de o contrato ser ou não equitativo. (...) o conflito de interesses não pressupõe que os interesses sejam opostos, mas que o acionista tenha duplo interesse".

Este argumento foi combatido pelo voto do diretor Luiz Antonio de Sampaio Campos, que buscou definir com mais clareza, fazendo uma análise mais profunda da doutrina nacional e estrangeira, sobre o que seria o verdadeiro conflito de interesses. Esse diretor, único a manifestar-se contrariamente ao voto vencedor, asseverou que o conflito de interesses seria aquela situação onde não existiria a possibilidade de convergência ou conciliação entre esses dois interesses, sendo inevitável que se sacrifique um em face do outro. Em seu voto, aduz, ainda, que a caracterização do conflito só poderia ser verificada a posteriori, em uma análise aprofundada do caso concreto. Conforme veremos:

“(...) deve-se permitir ao acionista [controlador] votar, na suposição de que ele não faltará com os deveres que lhe são impostos no artigo 115, caput, e no artigo 116, parágrafo único (...); mas comprovado, por ligeiramente que seja, que este faltou com o seu dever, seu voto será tido como ilegal e a deliberação poderá ser anulada, se este voto tiver sido determinante para a formação da maioria necessária à validade da deliberação."

Marcelo Fernandes Trindade discordou do voto de Norma Parente no que tocante ao abuso do direito de voto pelos diretores da companhia. Segundo ele, não havia elementos probatórios que pudessem levar a conclusão de que o voto tivesse sido exercido em prejuízo da companhia, ou que as condições contratuais não fossem equitativas. Entretanto, acompanhou a relatora no que concerne à abstenção do exercício do voto, não com base no conflito de interesses, mas por entender que a contratação com a companhia enquadrar-seia na hipótese do benefício particular: 
“(...) entendo que na deliberação sobre a celebração de um contrato bilateral entre a companhia e o acionista está previamente impedido o voto deste último, não porque enxergue necessariamente no contrato um conflito de interesses - interesses que, aliás, normalmente convergem -, mas porque nele vejo um benefício particular (a contraprestação), benefício este que, concedido ao acionista contratante, não é estendido aos demais acionistas, por razoes óbvias. (...) A meu juízo, nesses casos o acionista deve abster-se de votar, em obediência à regra do $\S 1^{\circ}$ do art. 115 da Lei 6.404/76, pois a regra do impedimento do voto deve ser posta em prática previamente à deliberação."

Os diretores Wladimir Castelo Branco Castro e José Luiz Osório de Almeida Filho acompanharam o voto da relatora. Todavia, este, acrescentou o seguinte:

“(...) entendo que à CVM não cabe analisar o mérito desses contratos [de royalties], substituindo o acionista no exercício do seu poder de voto. Porém, deve ela cuidar para que haja a devida transparência acerca das circunstâncias que envolvem esse tipo de contratação.”

Este Processo foi posteriormente alvo do Recurso Voluntário 4120, perante o Conselho de Recursos do Sistema Financeiro Nacional ("CRSFN"), órgão recursal na esfera administrativa e vinculado ao Ministério da Fazenda. Este órgão, contudo, negou - por maioria de votos - o provimento do recurso por entender que a interpretação mais adequada para a parte final do dispositivo em tela deveria ser que o voto do acionista que se considerar em conflito é vedado a priori. Entretanto, acrescentou o CRSFN que é o próprio acionista quem deve julgar se está ou não conflitado e se ele não o fizer, essa situação deverá ser verificada em fase ulterior, levando-se em conta apenas os aspectos formais. Manteve, assim, a decisão da CVM.

Como veremos no caso seguinte, o entendimento expressado no voto do diretor Luiz Antonio, que defendeu a tese de que o conflito de interesses seria 
material, passou a ser o entendimento majoritário da CVM, após o julgamento do Caso PREVI-SISTEL, em 1999.

\subsection{Caso PREVI - SISTEL}

Em 30 de novembro de 1999, os acionistas da Tele Norte Leste Participações S.A. (“TNLP”) aprovaram, em assembleia geral extraordinária, um contrato de prestação de serviços gerenciais entre a TNLP e sua controladora, a Telemar Participações S.A. (“TELEMAR”).

O Processo Administrativo Sancionador CVM no TA/RJ2002/1153, julgado em 06.11.2002, onde se verificou a possibilidade de a Previ e a Sistel, na qualidade de acionistas da TNLP, votarem na assembléia geral da TNLP. Que aprovou a celebração de um contrato entre a Telemar, controladora da TNLP, e as concessionárias controladas pela TNLP. Em resumo, a Previ e a Sistel possuíam tanto participação direta na controlada TNLP, quanto indireta na controladora, TELEMAR, o que configuraria o interesse conflitante para votar sobre o contrato entre aquelas empresas (TNLP e Telemar).

Mesmo com a abstenção da TELEMAR na deliberação da assembléia, a SEP acabou sendo favorável à abertura de inquérito administrativo, fundamentando o seu parecer na hipótese de ter ocorrido um possível conflito de interesse, visto que a Caixa de Previdência dos Funcionários do Banco do Brasil ("PREVI") e a Fundação Sistel de Seguridade Social ("SISTEL") possuírem participações indiretas na TNLP e diretas na TELEMAR. Asseverou , ainda, em seu parecer, a possibilidade de eventual punição aos acionistas em tese conflitados que exerceram o seu direito de voto na assembléia.

Nesse caso a Diretora Norma Parente firmou, novamente, o entendimento que o conflito de interesse é de ordem formal. Na oportunidade, 
a relatora diferenciou, inicialmente, o voto abusivo e o conflituoso. Alegou a Diretora, que a primeira hipótese, há necessariamente, uma avaliação substancial do voto, a posteriori, a fim de se verificar o abuso do voto. $\mathrm{Na}$ outra situação, de conflito, a lei teria proibido o acionista de votar. Dentre outras justificativas, já conhecidas da autora:

“(...) tem-se que o conflito de interesses ocorre sempre que o acionista encontra-se em posição dupla frente à sociedade. Ao mesmo tempo em que ele possui o dever legal de votar em favor dos interesses da sociedade, surge o seu interesse privado na outra ponta, de modo que é impossível atender plenamente aos dois, sendo inevitável o sacrifício de um em nome do outro. Para evitar que o interesse social seja renunciado pelo acionista, a lei 6.404/76 impediu o mesmo de deliberar nas assembléias em que possa haver o conflito.” (voto Norma, p. 11)

O colegiado, no entanto, acompanhou o voto do Diretor Relator Wladimir Castelo Branco, que seguiu a ordem do conflito substancial, no qual se afirmou:

“(...) acionista controlador ou não, deve exercer seu direito de voto no interesse da companhia. Se houver, por conseguinte, uma desobediência, a esse principio, estará caracterizado abuso do direito de voto e, no caso específico, o conflito de interesses."

O Diretor Luiz Antonio de Sampaio Campos também apresentou sua declaração de voto, para reafirmar a posição de que o conflito de interesses, na sua acepção técnica, deve ser substancial, efetivo e inconciliável. Levou-se em consideração, no caso, o principio da presunção de boa-fé, no sentido de que não seria possível, antecipadamente concluir-se pela intenção de um acionista de votar, em situação aparente de conflito, contra os interesses da companhia.

Por fim, o Diretor Leonardo Cantidiano, em seu voto, concluiu que a norma em análise deve ser interpretada da seguinte forma: 
“Olhando a parte final do $\S 1^{\circ}$ pelo outro lado, verifica-se que se a deliberação não puder beneficiar o acionista de modo particular e/ou se o seu interesse estiver sintonizado com o interesse da companhia ele estará admitido a votar. Ele poderá votar. Ele poderá votar. Pois bem, no caso concreto o interesse da acionista Telemar e de suas acionistas indiretas, (que são os acusados PREVI e SISTEL), era a meu ver convergente com o interesse da companhia que obteria, em razão do contrato celebrado, uma assistência técnica de experientes e bem sucedidos empresários, o que proporcionaria melhor desempenho das atividades que as companhias operacionais adquiridas no processo de privatização pretendiam desenvolver."

Todavia, após decisão da CVM nesse caso, o entendimento acabou sendo reformado pelo CRSFN por meio do Recurso 4585. O órgão recursal manteve a linha de entendimento adotada no caso TIM de que a situação de conflito no exercício do voto do acionista em assembléia estaria configurado considerando aspectos meramente formais.

Inobstante o posicionamento do órgão recursal, a CVM acabou mantendo o entendimento baseado na doutrina materialista do conflito de interesses, como veremos no caso seguinte.

\subsection{Caso AMBEV}

Em 2004 foi anunciada a maior reestruturação societária ocorrida em companhias abertas no Brasil, até então.

Nessa reestruturação, houve uma permuta de ações entre os acionistas da Braco S.A. ("BRACO") que era a controladora da AMBEV, com a INTERBREW, que alterou sua denominação para Interbrew AmBev S.A. ("INBEV"). A companhia que resultou da operação descrita emitiu 141,7 
milhões de ações em favor dos acionistas daquela, e recebeu diretamente as ações de BRACO controladora da AMBEV.

Como resultado, no final da estruturação do grupo econômico, haveria uma Holding que foi denominada STICHTING, com o capital social dividido entre os antigos acionistas da BRACO e com a IMBEV, a primeira com $44 \%$ (quarenta e quatro por cento) de participação, a segunda com 56\% (cinqüenta e seis por cento). Inobstante a diferença na posição acionária da holding, o controle era exercido por ambos os acionistas de maneira igualitária.

A STICHTING, por sua vez, passou a deter o controle da INBEV, com 56\% do seu capital. O restante ficou dividido entre os antigos acionistas da INBEV com $18 \%$ (dezoito por cento) e o free float com $26 \%$ (vinte e seis por cento).

Em paralelo, decidiu-se, foi decidido em assembleia geral extraordinária, que a AMBEV emitiria 19,3 bilhões de ações em favor da INBEV em troca de $100 \%$ das ações da Labatt Brewing Canadá Holding Ltd. (“LABATT"), empresa detida pela INBEV.

Por tanto, no final da reestruturação societária do grupo a IMBEV detinha indiretament aproximadamente 57\% (cinquenta e sete por cento) do capital da AMBEV. Do restante, $8 \%$ do capital eram detidos pela FAHZ fundação ex-controladora da Companhia Antarctica Paulista S.A. - e 35\% do capital dispersos pelo Mercado.

Observando a operação, a PREVI, em abril de 2004, apresentou reclamação à CVM, sob o fundamente de uma suposta irregularidade, quando da permuta de ações ocorridas no processo de incorporação LABATT. A reclamação não foi aceita pela SEP, motivo pelo qual, a PREVI interpôs 
recurso perante a CVM, alegando que poderia ter ocorrido a prática de abuso de poder e consequentemente possibilidade de ter ocorrido conflito de interesse, além de outras alegações, quanto ao exercício do voto dos então acionistas controladores da AMBEV. Com a interposição do recurso, foi instaurado o Processo CVM n ${ }^{\circ}$ RJ2004/5494, no qual a autarquia buscou averiguar o ocorrido no caso concreto.

Em suas alegações, o fundo de investimento alegava que a incorporação da LABATT era condição para a permuta de ações. Impondo essa condição, os acionistas controladores da AMBEV estariam em posição de conflito de interesse e deveriam ter se abstido de votar na deliberação que aprovou a incorporação.

O Colegiado da CVM, no julgamento desse processo administrativo, que ocorreu no dia 16 de dezembro de 2004, acabou por rejeitar a instauração de um inquérito administrativo, sob o fundamento de não haver indícios de que a operação em questão teria sido realizada observando o interesse exclusivo da BRACO, em detrimento dos interesses dos demais acionistas da AMBEV.

O diretor Wladimir Castelo Branco Castro, então relator e voto vencedor no julgamento, foi partidário da posição de que a verificação do conflito deveria ser realizada em momento posterior ao exercício do direito de voto dos acionistas, sob uma análise de conflito substancial de interesses, como já havia se manifestado em julgamentos pretéritos.

Afirmou, ainda, que o caso concreto, poderia sequer ser alvo de alegação de conflito de interesses, nos moldes do parágrafo $1^{\circ}$ do artigo 115 da Lei das S.A., visto que se tratava de incorporação de empresa sob controle comum e que, portanto, deveria ser aplicado o disposto no artigo 264, caput e parágrafo $4^{\circ}$ da Lei das S.A.. Lembrou que a incorporação da LABATT havia 
ocorrido quando a INBEV já havia se tornado acionista indireta da AMBEV e, consequentemente, a ter um acionista controlador comum.

Marcelo Trindade acabou acompanhando na íntegra o voto vencedor, do diretor relator, no tocante a conflito de interesses do acionista controlador.

A diretora Norma Parente acabou divergindo do voto vencedor, abarcando novamente a visão do conflito de interesse material e que mesmo apresentando fases distintas, que a operação deveria ser analisada em conjunto, ainda mais com a presença da permuta de ações como fator condicionante da operação. Aduziu que, portanto, não seria caso para a aplicação do parágrafo $4^{\circ}$ do artigo 264 da Lei das S.A., mas sim o parágrafo $1^{\circ}$ do artigo 115 do mesmo diploma legal. Então, de acordo com este entendimento, entendeu que houve abuso de poder no exercício do voto da BRACO e que na linha do conflito formal de interesses, a mesma estaria conflitada.

\subsection{Caso TRACTEBEL}

Visto como um dos principais casos julgados pela CVM. É tido como leading case, quando se refere à questão de conflitos de interesse no Brasil, foi o caso envolvendo a empresa Tractebel Energia S.A. ("TRACTEBEL”), no qual, por meio do Processo Administrativo CVM no RJ 2009/13179, a autarquia manifestou suas mais recentes visões sobre o tema.

Em 21 de dezembro de 2009, a TRACTEBEL divulgou fato relevante sobre a aprovação, em sede de seu conselho de Conselho de Administração, da celebração de um contrato de compra de 99,99\% (noventa e nove vírgula noventa e nove por cento) das ações de emissão da Suez Energia Renovável S.A., então sob a titularidade de GDF Suez Energy Latin America 
Participações Ltda. (“GDF”), sua acionista controladora. Em momento posterior, como manda Lei das S.A., por força do seu artigo 256, a proposta da compra das ações, seria ainda apreciada e sujeita à deliberação da assembleia geral extraordinária da TRACTEBEL.

Após rápido questionamento e pedido de esclarecimentos, a SEP determinou que a GDF deveria se abster de votar na assembleia que deliberasse sobre a aquisição das ações, fundamentando sua decisão no disposto no parágrafo $1^{\circ}$ do artigo 115 da Lei das S.A.. A SEP aduziu que a GDF na condição de acionista, deveria se abster de votar em deliberação que aprovasse um contrato com envolvimento de parte relacionada, visto que poderia, utilizando seu peso como acionista controladora, estar se beneficiando de modo particular, ficando dessa forma, caracterizado o conflito de interesse com sua controlada.

Com argumento fundamentado no Parecer de Orientação CVM no 35 , visto que a TRACTEBEL havia criado um comitê especial independente que negociaram algumas condições da contratação em questão. A TRACTEBEL apresentou recurso, solicitando que fosse excluída da decisão que determinou o impedimento de voto da acionista controladora o contrato de aquisição das ações.

No julgamento do recurso, que originou o Processo Administrativo $\mathrm{n}^{\mathrm{o}}$ RJ 2009-13179, acabou prevalecendo o entendimento de que a acionista controladora não poderia participar da decisão sobre a celebração do contrato que envolvia a TRACTEBEL e outra empresa do mesmo grupo. Inclusive, entendeu-se, por maioria de votos, que a criação de um comitê especial independente não seria suficiente para afastar o conflito de interesses na negociação. 
Inicialmente, podemos ressaltar algumas considerações interessantes contidas no voto do Diretor-Relator Alexsandro Broedel Lopes:

“(...) como se vê, no desenvolvimento da corrente doutrinária, os defensores do conflito material afirmam que os acionistas, quando em conflito de interesses, podem votar. Mais do que isso, alguns sugerem que o acionista em conflito deva votar, pois, do contrário, não haveria voto anulável e, portanto, não seria possível emanar conclusão sobre o verdadeiro resultado da deliberação, em eventual litígio para discutir a ocorrência ou não do conflito de interesses."

Em crítica à corrente dos defensores do conflito material, o Diretor afirma:

"Com o devido respeito aos ilustres defensores da corrente materialista, tenho algumas reservas sobre as suas conclusões.

Primeiro, de uma análise do texto da lei em estudo, noto que parágrafo $1^{\circ}$ do artigo 115 da Lei 6.404/76 diz, expressamente, que "o acionista não poderá votar" em quatro situações, sendo uma delas quando "tiver interesse conflitante com o da companhia". Dessa leitura, e com a devida vênia, não entendo que a melhor interpretação do texto referido seja aquela que exclui a negativa da lei, para concluir que o acionista "poderá votar", em situação de conflito.

Além disso, não me parece que a previsão legal das relações entre as sociedades coligadas, controladoras e controladas, bem como de grupos societários, seja contraditória com a proibição do voto. Entendo que a lei dá tratamento distinto para situações também distintas. O fato de a lei permitir que a Companhia contrate com um de seus acionistas não é contraditório com a proibição de voto nos casos de conflitos de interesses, oriundos, por exemplo, do próprio contrato a ser firmado. Ainda que não persista o voto do acionista contratante, o contrato poderá ser proposto e firmado pela Companhia, conquanto haja a aprovação dos demais acionistas.

Por outro lado, mostra-se coerente o argumento de que até o advento da Lei 6.404/76 não estava explícito o conflito de interesses como uma das hipóteses de proibição de 
voto. Assim, entendo que a sua inclusão seria um ótimo indicativo da intenção do legislador de proibir, efetivamente, o voto do acionista, nessa hipótese"

Afirma, ainda, que o Parecer CVM n 35 deixaria expresso que a sua aplicação é direcionada, especificamente, para as hipóteses tratadas no artigo 264 da Lei das S.A., que criou um regime especial para as operações de fusão, incorporação e incorporação de ações envolvendo sociedade controladora e controlada ou sob controle comum. Portanto, a criação do comitê independente, nos moldes do Parecer, não afastaria a incidência do parágrafo $1^{\circ}$ do artigo 115 da lei societária.

Em sua decisão final, a CVM, por maioria dos votos e capitaneada pela posição da então presidente Maria Helena, manifestou-se concluindo que a TRACTEBEL, estaria impedida de votar na assembleia que fosse deliberar sobre a celebração do contrato em que a mesma ou sociedade por ela controlada figurasse como contraparte. E que mesmo com a criação de um comitê independente constituído nos termos descritos na Consulta, o acionista controlador da TRACTEBEL, estaria impedida de exercer o voto. E tal posição foi acolhida, tendo, portanto, os minoritários no poder de decisão da compra. Uma jurisprudência inovadora. ${ }^{31}$

Marcos Barbosa Pinto, então, corroborou com a maioria dos seus colegas, descrevendo em seu voto toda a evolução do entendimento jurisprudencial no âmbito do tema de conflito de interesses, analisando as questões próprias do nosso ordenamento jurídico e uma breve dissertação sobre a eficiência econômica de cada uma das formas de interpretação.

O diretor Otavio Yazbek que, também se manifestou no mesmo sentido, fundamentando-se no professor Fabio Konder Comparato, aduzindo que

\footnotetext{
${ }^{31}$ Jornal Valor, dia 15,16 e 17 de outubro de 2010.
} 
inicialmente o juízo sobre a situação de conflito de interesses deve ser feito pelo próprio acionista.

Acrescentou, ainda, que caso a situação de conflito, não fosse identificada nesse primeiro momento, que caberia ainda a anulação do voto que posteriormente se demonstrou conflitado. Em seu voto, afirmou que mesmo presumindo-se a boa-fé das partes, quando existe dispositivo legal estipulando um regime específico de prevenção, este deveria prevalecer.

O único voto em sentido contrário ao do relator foi o do diretor Eli Loria que, seguindo a corrente substancial, defendeu que se a operação estivesse sendo realizada de acordo com as práticas de mercado, não haveria motivos para a anulação do voto.

Todavia, em assembléia geral extraordinária no dia 19 de outubro de 2010, registrada a abstenção da GDF, a operação foi aprovada por unanimidade dos demais acionistas.

\subsection{Outras considerações}

Em outros casos que foram levados até o conhecimento do Colegiado da CVM, pudemos observar posicionamentos diversos. Os defensores do conflito substancial entenderam que o qualquer medida de controle do caso em questão, deveria ser tomada em momento posterior, por meio da analise do resultado da deliberação. Como já vimos acima, os defensores dessa segunda teoria ressaltaram que o conflito de interesse deve ser extraoficial, estranho mesmo à relação social, devendo necessariamente se contrapor ao interesse social. Aduzem, ainda, que o conflito deve ser substancial e não meramente formal, e inconciliável como podemos verificar na Declaração de Voto do Diretor Luiz 
Antonio de Sampaio Campos, no Inquérito Administrativo $\mathrm{CVM} \mathrm{n}^{\circ} \mathrm{RJ}$ 2002/1153:

\begin{abstract}
"Nessa linha, primeiramente, deve ficar dito que o interesse em conflito há de ser extrasocial, não decorrente da situação de sócio do acionista. Este interesse extrasocial, estranho mesmo à relação social, é que deve se contrapor ao interesse social. A contraposição entre interesses de acionistas não autoriza a aplicação do parágrafo $1^{\circ}$ do artigo 115 da Lei $n^{\circ} 6.404 / 76$.
\end{abstract}

Mais ainda, esta contraposição, este conflito, deve ser substancial (e não apenas formal), efetivo e inconciliável. Seria aquele conflito de interesse que não permitiria a convergência ou a conciliação, mas que, para o atendimento do interesse de uma das partes, necessariamente se exigiria o sacrifício da outra parte. Para se alcançar um interesse, ter-se-ia invariavelmente que prejudicar o outro.

Em outras palavras, não basta que haja uma duplicidade de interesses no voto do acionista. Para que se caracterize o conflito de interesses mencionado na lei, tal duplicidade deve implicar obrigatoriamente um choque de interesses, uma colisão entre o interesse social e o do acionista, de modo que um não poderia prevalecer sem o sacrifício do outro."

Além dos julgados propriamente ditos, podemos considerar fonte de consulta para entendimento da jurisprudência no país, os pedidos de consultas públicas. Como a consulta solicitada pela AMEC - Associação de Investidores no Mercado de Capitais, em momento anterior à data de realização da Assembleia Geral Extraordinária da Petrobrás, a qual previa deliberação sobre uma Oferta Pública de Ações de ações que seria realizada pela Petrobrás. Na consulta, havia questionamento sobre os procedimentos relacionados à Oferta Pública, bem como a participação União em tal deliberação, visto que a mesma poderia estar impedida face inteligência do§ $1^{\circ}$ do Artigo 115 da Lei das S.A..

No caso em questão, a AMEC aduziu que a união estaria impedida de votar na Assembleia Geral que iria deliberar sobre as questões pertinentes ao 
laudo de avaliação, com fundamento no disposto no $\S 1^{\circ}$ do art. 115 da Lei 6.404/76, pois necessariamente, a União deveria participar da oferta para integralização das ações. Na oportunidade, a CVM entendeu que a união estaria impedida de votar na referida Assembleia Geral.

No Processo CVM no RJ 2006/6785, a autarquia também apresentou sua posição sobre algumas questões como se quando uma vez impedido de votar o acionista titular de uma classe ou espécie de ações, ficaria impedido de votar como titular de outra classe ou espécies de ações. Ou seja, se o impedimento diz respeito à pessoa do acionista atingindo, assim, todas as ações por ele detidas, ou se apenas as pessoas beneficiadas com a operação. $O$ colegiado da CVM, no referido processo, decidiu a questão da seguinte forma, tendo prevalecido nesse ponto o voto do então presidente Marcelo Trindade:

\footnotetext{
"Assim, quando o impedimento de voto decorrer de um benefício que seria obtido por força de uma situação subjetiva, isto é, ligada à pessoa do acionista, o impedimento será desta pessoa, quaisquer que sejam as ações de sua titularidade, e com todas elas. Dessa natureza são as duas primeiras hipóteses mencionadas pelo Parágrafo $1^{\circ}$ do art. 115 da Lei das S.A. De outro lado, quando o impedimento de voto decorrer de um beneficio que objetivamente atinja toda uma classe e espécie de ações, isto é, à toda categoria de acionistas - como ocorre nas hipóteses do Parecer de Orientação n 34 -, o impedimento não alcançará a pessoa do acionista, com as demais ações de que seja titular, de outra classe ou espécie não impedida de votar."32
}

\footnotetext{
${ }^{32}$ Processo Administrativo CVM no RJ2006/6785, voto do Presidente Marcelo Trindade. Disponível no site da CVM.
} 


\section{CAPÍTULO 3}

\section{Conflito de Interesses de Administradores}

Segundo a doutrina moderna, administradores são agentes acionistas na companhia. Em outras palavras, eles têm mandato para exercer a vontade dos acionistas. Portanto, sua posição de supervisor dos negócios sociais ou gestor do patrimônio da companhia lhe dá uma situação privilegiada quanto à realização de negócios de resultados vantajosos.

A Lei das S.A. apresenta em seus artigos de 153 a 159, a disciplina das vedações impostas aos administradores no exercício de suas funções. Nos artigos 153 a 157 do referido diploma, o legislador optou por apresentar um descritivo dos deveres dos administradores e no artigo 158, veio disciplinar a responsabilidade dos administradores.

Podemos considerar que às funções de administrador, devem ser exercidas em observância aos deveres legais estabelecidos nos artigos mencionados e poderíamos considerar que o dever de lealdade, per si, bastaria para que o administrador fosse impedido de manifestar o seu direito de voto em casos de conflito de interesses.

Todavia, existe, ainda, uma proibição expressa na lei que vedaria o administrador de votar, quando estivesse em condições nas quais pelo exercício de sua função pudesse de beneficiar, podendo apenas contratar com a sociedade em condições razoáveis e equitativas de mercado, sem que pudesse ser verificado nenhum privilégio ou facilidade para a realização da operação.

A ideia do legislador seria a de realização de negócios, como se os mesmos fossem ser praticados por terceiro não administrador, em estrita condição de mercado. 
A divisão entre deveres e responsabilidades se mostra pertinente, visto que poderia indicar que os deveres são pretéritos às responsabilidades e que seriam princípios independentes entre si. Podemos destacar quando aduz no parágrafo $1^{\circ}$ do artigo 115 no sentido que o administrador-acionista não pode votar em conflito de interesses com suas próprias ações ou ações nas quais é legitimado para exercer o direito de voto.

Caberia, portanto, ao administrador, dar ciência aos demais administradores, quando este se julgar impedido, fazendo o registro cabível em ata de reunião própria "a natureza e extensão do seu interesse". Na mesma linha, o autor J. C. Sampaio Lacerda:

“(...) Se no exercício dessas atividades resultar antagonismo entre os interesses da companhia e os do administrador, estará este impedido de intervir na operação social, bem como de votar na deliberação que a respeito tomarem os demais administradores, cumprindo-lhe ainda cientificá-los do seu impedimento e fazer consignar, em ata da reunião do conselho de administração ou da diretoria, a natureza e a extensão do seu interesse (art. 156).,33

Na mesma linha de raciocínio, podemos dar destaque à posição do autor Wilson de Souza Campos Batalha:

"O preceito vigente esclarece a obrigatoriedade de ser consignada em ata de reunião do conselho de administração ou da diretoria a informação prestada pelo administrador interessado, relevando a natureza e extensão de seu interesse, ademais; esclarece que o negócio deve ser normal, em condições de mercado. Finalmente, o negócio celebrado com infração da norma que exige condições normais ou equitativas é anulável, transferindo-se para a companhia as vantagens irregularmente auferidas pelo administrador."34

\footnotetext{
${ }^{33}$ LACERDA, J. C. Sampaio, Comentários ás Leis das Sociedades Anônimas art. 121 à 165, ed. Saraiva.

${ }^{34}$ BATALHA, Wilson de Souza Campos, Comentários À Lei das Sociedades Anônimas, ed. Forense, 1977, p. 709.
} 
Entretanto, podemos verificar que o texto legal não veda que o administrador negocie com a companhia, impondo apenas que o mesmo não intervenha nas negociações,

E isto porque, se interviesse, estaria se na posição de diretor, atuando ao mesmo tempo como representante orgânico da companhia e da outra parte e, se conselheiro de administração, estaria deliberando a respeito de um negócio no qual ele teria interesse pessoal. E inegável a incompatibilidade, partindo do conceito que não pode a mesma pessoa assumir, simultaneamente, posições conflitantes.

Sobre a aparente incompatibilidade, destacamos a posição de Modesto Carvalhosa:

"O impedimento imposto pela lei aos administradores é de dupla natureza: de representação e de deliberação. Evidentemente que este último e mais abrangente do que o primeiro, incluindo-se nele todos os administradores, mesmo aqueles que, por serem membros do Conselho de Administração, não têm a representação da companhia (art. 138). ${ }^{.35}$

Corroborando com o acima aduzido, damos destaque ao Processo Administrativo Sancionador CVM n $n^{\circ} 25 / 03^{36}$, julgado em 25 de março de 2008 .

A acusação baseava-se no fato de administradores da TNL trabalharem também na TELEMAR, estando em aparente posição de conflito de interesses, quando fossem apresentar suas deliberações. E que seria, portanto, uma celebração de negócios entre controlador e controlada com administradores em comum, violando o dever de evitar conflito. Neste sentido, destacamos apenas

\footnotetext{
${ }^{35}$ CARVAlHOSA, Modesto, Comentários à Lei das Sociedades Anônimas, vol. $2^{\mathrm{o}}, 4^{\mathrm{a}}$ edição, $2^{\mathrm{a}}$ tiragem, São Paulo: ed. Saraiva, 2009, p. 273.

${ }^{36}$ Disponível no site da CVM.
} 
o voto da Presidente da CVM à época, Maria Helena, em conclusão do PAS CVM no 25/03.

"A meu ver, a leitura do caput do art. 156 deixa claro que o administrador pode contratar com a companhia em situação de conflito de interesses, mas o exclui de todo o processo de tomada de decisão ou contratação do negócio, garantindo, dessa forma, que o processo de contratação será do ponto de vista da companhia, pautado no seu melhor interesse. E, pelos $\S \S 1^{\circ}$ e $2^{\circ}$ daquele artigo, vê-se nitidamente que a preocupação do legislador foi a de garantir que o negócio celebrado pela companhia em situação em que o administrador possua interesse conflitante seja feito em bases eqüitativas. Nesse contexto, entendo que o art. 156 da Lei das S.A. necessariamente pressupõe a existência de interesse pessoal do administrador, concorrente e oposto ao interesse da companhia.

Isso porquê, obviamente, o interesse pessoal do administrador deve ser forte o suficiente para comprometer a fiel observância dos deveres legais previstos nos artigos 153 a 155 da Lei das S.A, segundo os quais os administradores são legalmente compelidos a agirem com cuidado e diligência, exercendo suas atribuições para lograr os fins e o interesse da companhia, e com lealdade. Portanto, para que ficasse configurado o conflito de interesses neste caso, seria necessária a demonstração desse interesse pessoal e colidente do administrador. Não julgo que o fato de os acusados serem administradores tanto da TNL quanto da Telemar, empresas contrapartes na operação, seja suficiente para provar a existência desse interesse."

A adoção de tais medidas buscaria em tese evitar que o administrador influencie indiretamente ou diretamente os negócios de uma Companhia, buscando a manutenção da idoneidade da gestão social e dos interesses da sociedade como um todo.

Com relação às sanções, o negocio contratado com infração do disposto no $\S 1^{\circ}$ do art. 156 da lei das S.A, seria anulável, assim sendo, fica a legitimidade do negócio dependente de ato posterior, podendo ser validada a 
operação, quando produzira ela todos os efeitos. Se, entretanto, o negócio for anulado, o administrador interessado, com reparação dos danos sofridos pela sociedade, fica obrigado a transferir a esta, as vantagens que houver auferido na operação.

Poderá, ainda, ser anulável uma transação caso seja realizada sem que o administrador tenha tido a cautela de observar o disposto no caput do art. 156 da Lei das S.A:

“Art. 156". É vedado ao administrador intervir em qualquer operação social em que tiver interesse conflitante com o da companhia, bem como na deliberação que a respeito tomarem os demais administradores, cumprindo-lhe cientificá-los do seu impedimento e fazer consignar, em ata de reunião do conselho de administração ou da diretoria, a natureza e extensão do seu interesse.

$\S 1^{\circ}$ Ainda que observado o disposto neste artigo, o administrador somente pode contratar com a companhia em condições razoáveis ou eqüitativas, idênticas às que prevalecem no mercado ou em que a companhia contrataria com terceiros.

$\S 2^{\circ} \mathrm{O}$ negócio contratado com infração do disposto no $\S 1^{\circ}$ é anulável, e o administrador interessado será obrigado a transferir para a companhia as vantagens que dele tiver auferido."

Isto é, quando o administrador, por exemplo, participe de uma deliberação acerca de uma operação social em que ele tinha interesse conflitante com o da companhia, deixando de cientificar aos demais administradores. O direito de invocar a anulabilidade do ato pertence à sociedade, que poderá ter obtido vantagem com a transação e não lhe convir, assim, desfazê-la. ${ }^{37}$

\footnotetext{
${ }^{37}$ LACERDA, J. C. Sampaio, Comentários à Lei das Sociedades Anônimas, ed. Saraiva, 1978 - v.3 (arts. 121 a 165); Coordenação de Arnoldo Wald
} 
Portanto, as sanções para a hipótese de descumprimento da vedação em foco são de duas ordens. De um lado, fica o administrador com a obrigação de "transferir para a companhia as vantagens que dele tiver auferido" ${ }^{38}$. Uma solução considerada justa, pois as vantagens foram indevidamente obtidas, e o foram em detrimento da companhia. Que poderia ter negociado com terceiros, em melhores condições. A outra sanção atinge o próprio negócio, que a lei declara anulável.

Por sua vez, o autor Paulo Fernandes Campos Salles de Toledo, afirma que o legislador poderia ter feito mais:

"O legislador, no entanto, poderia ter ido além, e invalidar por completo o negócio, inquinando-o de nulidade. É perigoso deixar, ao administrador que já se revelou inescrupuloso, a porta aberta da convalidação."39

\subsection{Discussão entre Conflito formal e substancial}

Diversos autores, como Modesto Carvalhosa, diferenciam a questão de conflito de interesses no âmbito dos administradores, em conflito formal e substancial.

A corrente formal sustenta que o legislador estabeleceu verdadeiro impedimento de voto para o administrador interessado, como medida cautelar para evitar eventual prejuízo à sociedade, devendo o administrador declarar-se impedido antes de qualquer deliberação, quando se julgar conflitado.

Todavia, os defensores da teoria formalista não relacionam $o$ impedimento de voto com a existência de um interesse pessoal que

\footnotetext{
${ }^{38}$ Lei $6.404 / 76$, art. $156 \S 2^{\circ}$.

${ }^{39}$ TOLEDO, Paulo Fernandes Campos Salles de, O conselho de Administração na Sociedade Anônima, São Paulo, ed. Atlas, $2^{a}$ edição, 1999, p.63.
} 
necessariamente importe sacrifício do interesse da companhia. Também não correlacionam a obrigação de não votar com a comprovação de que o beneficio particular do administrador acarrete efetivo dano para companhia.

Conforme assinala o próprio Modesto Carvalhosa, principal defensor dessa corrente, o fundamento da norma não consiste no pressuposto de que o administrador pretenderia votar e contratar contra o interesse social, mais sim no fato que, "não pode o administrador que será parte contratual formar a vontade de outra parte, que é ou será a companhia".

Ou seja, não de ser absolutamente imparcial na pode o administrador estar nos dois pontos da negociação, pois, nesse caso, o administrador não estaria em condições busca pelo atendimento do interesse social. Isso porque as partes antagônicas da contratação se confundiriam com a mesma pessoa.

O entendimento de Carvalho de Mendonça delineia o que se chama de conflito formal de interesses:

“(...) interesse oposto ao da companhia dá-se quando o administrador e parte em negocio que a sociedade esta para concluir com ele ou outros juntamente com ele; em negocio no qual tenha vantagem."40

Miranda Valverde vê a existência ou não de interesse, contrário ou oposto como uma questão de fato, a ser apreciada em cada caso. ${ }^{41}$

Nessa linha cumpre mencionar o voto da Diretora Relatora Maria Helena no PAS CVM n²005/0097 julgado em 15.03.2010, que tratou da infração à proibição de intervir em negócio em que tenha interesse conflitante com o da companhia. Onde Alexandre Beldi Netto, Marco Antonio Beldi e Antonio Fábio Beldi, acionistas da Splice/Fixcel e membros do conselho de

\footnotetext{
${ }^{40}$ MENDONÇA, Carvalho, Tratado, vol.2, p. 64

${ }^{41}$ VALVERDE, Miranda, Sociedade por Ações, vol.2, p.315
} 
administração da TCO, dentre outras, foram acusados pela SEP de infração ao art. 156 da Lei 6.404/76, considerando que, como acionistas da Splice/Fixcel e administradores da TCO, tinham interesse na aprovação do empréstimo, que diminuiria o caixa da TCO e não possuía garantias suficientes, ainda que possa ser considerado que o custo médio de aplicação fosse maior que o de captação. Deveriam, portanto, ter se declarado impedidos na deliberação como conselheiros da TCO, e assim infringiram o art. 156 da Lei 6.404/76. Considerando que, como acionistas da Splice/Fixcel e administradores da TCO, deveriam ter-se declarado impedidos, haja vista que tinham interesse na aprovação de um negócio - o empréstimo - que iria diminuir o caixa da TCO e não gozava de garantias suficientes, ainda que se considere que o rendimento médio de aplicação era maior que o custo de captação.

Segue o voto da Diretora relatora Maria helena:

“(...) entendo que esses administradores da TCO tinham interesse conflitante com o da Companhia nas deliberações objeto deste processo e, portanto, atendendo ao comando da lei, deveriam ter deixado de votar e ter, ainda, exposto nas atas a natureza de seu interesse. Entendo, ademais, que também poderia ter sido imputada esta mesma responsabilidade ao Sr. Mário César Pereira de Araújo, que além de conselheiro da TCO era também conselheiro da emissora, Fixcel (item 21-b do TA, às fls. 1143), pois na situação em que as duas empresas a que deveria servir tinham interesses conflitantes, esse administrador não poderia ter participado das deliberações. Como, no entanto, essa acusação não foi feita, não seria possível punilo por isso."

A pena foi de suspensão por um ano para o exercício do cargo de administrador ou conselheiro fiscal de companhia aberta, de entidade do sistema de distribuição ou de outras entidades que dependam de autorização ou registro na CVM, na forma do inciso III do art. 11 da Lei 6.385/76, a Alexandre Beldi Netto, Marco Antonio Beldi e Antonio Fábio Beldi, acionistas 
da Splice e da Fixcel, além de membros do conselho de administração da TCO, por: infração ao art. 153 da Lei 6.404/76; e infração ao art. 156 da mesma lei.

Portanto, o administrador interessado deve como já mencionado acima, cientificar o impedimento aos seus pares, fazer consignar em ata de reunião do Conselho a natureza e extensão do seu interesse e simplesmente abster-se de votar. Pois não haveria espaço para que o administrador sequer delibere, segundo a corrente formal.

Seguindo essa visão, não há que se perquirir se o voto do administrador efetivamente privilegiaria seu interesse pessoal em detrimento do interesse da sociedade, ou não. Em outras palavras, a conseqüência da infração da proibição de voto é, para a corrente formal, a anulação da deliberação, ainda que o interesse social tenha, ao final, preponderado.

A $4^{\circ}$ Turma do STJ, ao julgar o REsp 156.076-PR, de relatoria do Min. Ruy Rosado de Aguiar, acolheu a interpretação formal do conflito de interesses, tendo decidido que este decorre "da simples existência de prestações contrapostas, contratualmente ajustadas".

No plano da CVM, a defesa da corrente formal se deu no julgamento do Processo CVM no RJ 2004/5.494, quando se entendeu haver conflito de interesses em operação de permuta de ações do controle de duas sociedades a qual foi aprovada com o voto de um administrador que também era controlador de uma das sociedades e que, assim, era um dos principais beneficiários da operação.

No mesmo sentido foi o posicionamento daquele órgão no julgamento do Inquérito Administrativo CVM n²001/4.977.

No entanto, são diversas as noções e as consequiências de conflito de interesses. Há, portanto que se falar no conflito qualificado substancial que é 
defendido pela maioria dos autores. Neste, configura-se um interesse lesivo ao da outra parte, adentrando-se no campo do ilícito.

$\mathrm{Na}$ esfera do direto societário, há conflito substancial quando a satisfação do interesse do administrador faz-se com o sacrifico do interesse social. Nesse caso o interesse do administrador não é apenas contrastante, ele se configura como prejudicial e, portanto, danoso ao patrimônio da companhia.

O conflito, portanto, se confirmará quando, após a análise do voto do administrador, se concluir que o interesse extra-social que o conduziu é colidente e inconciliável com o interesse social. Isto é, para o atendimento do interesse de uma das partes necessariamente deverá haver o efetivo sacrifício do interesse da outra. Não bastando que haja apenas um duplo interesse por parte do administrador, como defende a corrente formal.

Os materialistas defendem, ainda, que a regra do conflito de interesses formal seria insuficiente para a identificação de todos os possíveis casos de interesses conflitantes, haja vista que ela circunscreveria as hipóteses de conflito aquelas em que o administrador contratasse com a sociedade, quando, na verdade, podem ser verificados conflitos de interesses mesmo quando não há qualquer relação contratual entre administrador e sociedade.

Além disso, para a corrente em análise, a regra do conflito de interesses formal seria muito rigorosa, pois acabaria por impedir a realização de operações vantajosas para a sociedade pelo simples fato de a outra parte contratante ser o administrador ou pessoa de seu interesse.

Concluem, assim, os defensores da corrente material que o legislador teria proibido, cautelarmente, o administrador de votar. Mas, se este entender que não se encontra em situação de conflito e votar, deve-se analisar o modo como este votou, o conteúdo do voto e se efetivamente tiver havido sacrifício 
do interesses social, a deliberação deverá anulada, haja vista que o ato ilícito, para essa corrente, consiste em votar contra o interesse social, e não em votar tendo um interesse extra-social.

Temos no ordenamento jurídico, poucos casos aonde o tema foi analisado por órgão do poder judiciário, fugindo a esfera dos órgãos administrativos. A $4^{\mathrm{a}}$ turma do estágio STJ - que, como visto anteriormente, no julgamento do REsp 156.076-PR, havia adotado a interpretação formal do conflito de interesses, ao julgar o REsp 131.300-RS entendeu que a existência do conflito só é concretizada quando os interesses extra-social e social são efetivamente colidentes. Note-se que no julgado foi analisada de conflito de interesses por parte de acionista, e não por parte de administrador de sociedade anônima.

No âmbito da CVM também prevaleceram às teses da natureza material do conflito de interesses, como podemos observar no julgamento do Inquérito Administrativo CVM/RJ-2002/1.153, quando se entendeu que não tinha o condão de configurar conflito de interesses o simples fato de os acionistas votantes de terem participação acionária direta e indireta nas duas partes do contrato em questão. $\mathrm{O}$ voto condutor do julgamento menciona o principio da presunção de boa-fé do acionista, que poderia ser afastado pelo exame meramente formal e aparente do conflito de interesses. Ainda em resposta a corrente formal, afirmou-se que a presunção iuris et de iure do conflito de interesses exigiria a previsão clara de hipóteses especificas - o que não teria sido feito pela lei vigente. Assim, sustentou-se que quando há na lei mera referencia genérica e subjetiva, a analise inicial do conflito deve se dar primeiramente pelo acionista interessado, porquanto só ele tem condições, naquele momento, de avaliar a situação e somente ele sabe o teor do voto que proferia. 
O Conselho de Recursos do Sistema Financeiro Nacional, ao analisar o recurso interposto dessa ultima decisão, entendeu que o conflito de interesses pode e deve ser verificado pelo próprio administrador (rectius, "acionista") antes de proferir seu voto; e, sendo constatado sua existência, o exercício do voto é vedado a priori. Se, porém, o administrador (rectius, "acionista") entender que não há conflito de interesses, ele poderá votar, e o conteúdo do seu voto será objeto de analise posteriormente. Muito embora tenha havido, em sua essência, um direcionamento formal da referida decisão, pode-se verificar certa influencia material, portanto se admitiu a análise posterior do próprio conteúdo do voto do acionista.

Esta decisão do CRSFN reforça uma idéia de solução alternativa, uma necessidade de temperamento no caso de conflito de interesses. Podendo ser vista como uma situação conciliatória entre a profusão de interesses existentes na sociedade anônima, visão de autores de que a opção deve ser por uma alternativa média, uma solução intermediaria, nem só voltada para uma solução formalista pura, nem apenas para uma solução casuística radical.

Dentro desse quadro, Calixto Salomão Filho, destacou o trecho abaixo acerca do conflito de interesses:

\footnotetext{
“implica deslocar a questão da analise e comparação do ato e sua relação com o interesse social para a verificação da situação e dos deveres mínimos de cuidado de administradores e controladores. Retorna-se, como dito acima, portanto, aos deveres de cuidado e fiduciários não como disciplina substitutiva do conflito de interesses, mas como critério para sua apuração". ${ }^{2}$
}

Dessa forma, segundo a corrente doutrinária que defende uma solução mista para estes conflitos, a tradicional classificação entre conflito de interesses formal e material deveria ser "transformada em diferença entre

${ }^{42}$ FILHO, Calixto Salomão e COMPARATO, Fabio Konder, O Poder de Controle na Sociedade Anônima, ed. Forense, $5^{\text {a }}$ edição, 2008. 
situações em que se verifique forte perigo de comportamento incorreto e situações em que isso não ocorra".

Para que assim, havendo risco de inobservância pelo conselho de administração dos seus deveres fundamentais, deveria a ele ser imposto o impedimento de voto, a priori. Esse impedimento de participar da deliberação seria amplo, abrangendo também a proibição de "opinar, sugerir ou sob qualquer forma influenciar a deliberação dos órgãos da administração da companhia".

O raciocínio acima, contudo, não deriva apenas de interpretação puramente gramatical da lei, mas também, da constatação de que a formação da vontade social é realizada pelo próprio administrador, que tem deveres importantes para com a companhia.

Deveria ser ele, portanto, que, como membro integrante de um órgão da sociedade e parte de uma relação eminentemente fiduciária, exterioriza a vontade social. Assim, a conduta que se espera do administrador é a representação leal, diligente e transparente dos interesses da sociedade na negociação das condições do contrato que ela vier a celebrar ou de qualquer outra operação societária que vier a realizar, buscando sempre as melhores condições para a companhia.

Dessa forma, tal como defende a corrente formal antes analisada, não poderia aquele que representa os interesses de uma das partes, fixa a orientação geral dos seus negócios e negocia as melhores condições possíveis para ela, ao mesmo tempo, ser ou ter interesse direto na outra parte contratante ou auferir benefícios decorrentes da contratação ou operação em pauta, eis que the faltaria à necessária isenção. 
Nessa ordem de idéias, Fábio Konder Comparato e Calixto Salomão Filho, afirmam que ocorrerá impedimento de voto sempre que "o conflito de interesses transpareça a priori da própria estrutura de relação ou negocio sobre que se vai deliberar, como, por exemplo, um contrato bilateral entre a companhia e o acionista". ${ }^{43}$

Contudo, muitas vezes o conflito de interesses revela-se de forma camuflada, não-evidente, o que dificulta a imposição, a priori, pelos demais administradores, aquele administrador interessado, da regra de impedimento de voto. É comum que o interesse conflitante não envolva a celebração de um contrato bilateral, em que o administrador seja a contraparte direta da sociedade. Pode ocorrer que em alguma operação social o administrador tenha interesse indireto e não aparente na contraparte da sociedade, seja por receber algum beneficio pessoal em troca de seu voto, seja por ser sócio, ainda que indireto e longínquo, da contraparte. Em muitos desses casos o conflito só se exteriorizará para os demais administradores após o exame do conteúdo da deliberação.

Não há dúvidas, porém, de que a situação de conflito de interesses existe e é precedente a deliberação. A questão, contudo, é que esse conflito só se revela, a priori, internamente, para o próprio administrador. Sua verificação pelas demais pessoas é que, muitas vezes, só será possível a posteriori.

Nem por isso, todavia, deixa de existir para o administrador interessado o impedimento de voto. Nada obstante, se o administrador interessado não observar tal comando de não votar, é preciso cogitar a idéia de temperar a regra se admitir que, nesses casos, o conflito seja verificado a posteriori.

\footnotetext{
${ }^{43}$ FILHO, Calixto Salomão e COMPARATO, Fabio Konder, O Poder de Controle na Sociedade Anônima, ed. Forense, $5^{\mathrm{a}}$ edição, 2008.
} 
Assim, havendo afronta a regra clara de conduta prevista no art. Lei 6.404/1976, segundo esta corrente, dever-se-á apurar a posteriori e casuisticamente, com base no conteúdo do voto, se, ao votar, o administrador privilegiou seu interesse pessoal, violando seus deveres básicos de conduto. Em outras palavras, na prática se permitirá que o administrador vote, e posteriormente se analisará o modo pelo qual votou. Para se concluir pela sua atuação, ou não, no interesse da sociedade e de acordo com seus fins.

Se constatada a preferência pelo interesse pessoal do administrador, com prejuízo para a sociedade, a deliberação deverá ser anulada. Caso, porem, não seja privilegiado o interesse extra-social em detrimento do interesse social, a deliberação deverá prevalecer, pois não se anula o negocio não-danoso, de acordo com a regra do art.156 da Lei 6.404/1976.

Esclareça-se, por fim, que o Colegiado da CVM, ao julgar o Processo RJ-2007/3.453, decidiu que por "interesse extra-social", pessoal do administrador, deve-se entender apenas seu interesse próprio na negociação, seja direto ou indireto. O sentido do voto conflituoso do administrador deve ter por escopo, assim, a reversão de algum beneficio para ele próprio, ainda que seja o favorecimento de sociedade da qual ele participa como sócio ou o mero recebimento de um bônus pela contraparte da companhia, portanto, não configura conflito de interesses para a CVM.

Diante das considerações feitas anteriormente, conclui-se que segundo essa "corrente", a regra do conflito de interesses não pode ser lida apenas sob seu aspecto formal, sob pena de virar letra morta, uma vez que, nesse caso, não terá o condão de abranger inúmeras situações de conflito de interesses, deixando de proteger, muitas vezes, o interesse da própria sociedade.

A melhor interpretação da regra positiva no art.156 da Lei 6.404/1976 seria aquela que estabelece proibição cautelar de voto nos casos em que há 
forte e evidente perigo de comportamento incorreto e que permite o voto, mas, analisa a posteriori seu conteúdo, se o receio de violação pelo administrador de seus deveres fiduciários não é manifesto desde logo. Havendo deliberação com participação do administrador, o mesmo transfira para a sociedade as vantagens que tiver auferido do negocio contratado em conflito de interesses.

\subsection{O Parecer de Orientação no $35 / 08$}

Ainda no tocante ao conflito de interesses no âmbito dos administradores de uma sociedade anônima, como observamos no caso TRACTEBEL, aprofundado em um dos tópicos anteriores, foi determinante para a consolidação da posição dos diretores da CVM, o Parecer de Orientação CVM N ${ }^{\circ} 35$, de $1^{\circ}$ de setembro de 2008, que buscou atribuir deveres fiduciários dos administradores nas operações de fusão, incorporação e incorporação de ações envolvendo a sociedade controladora e suas controladas ou sociedades sob controle comum.

Por meio desse parecer a CVM elencou algumas recomendações aos administradores das companhias abertas, quando estes estiverem diante de procedimentos durante uma negociação de operação de fusão, incorporação ou incorporação de ações envolvendo sociedade controlada e suas controladas ou sociedades sob controle comum, visando propiciar uma melhor observância dos dispositivos legais do Direito Societário.

A principal preocupação da CVM pareceu ser a observância dos deveres fiduciários que a Lei das S.A. atribui aos administradores, que deveriam sempre defender os interesses da Companhia que administram e de seus acionistas, buscando a uma relação equitativa entre si. 
Segundo a CVM, a Lei das S.A. estabeleceu deveres fiduciários dos administradores, apenas de forma abstrata, cabendo à CVM, por meio do Parecer de Orientação $n^{\circ} 35$, orientar de maneira mais assertiva a conduta dos administradores de companhias abertas a respeito de procedimentos a serem seguidos nas operações de fusão, incorporação e incorporação de ações envolvendo sociedade controladora e suas controladas ou sociedades sob controle comum, conforme hipótese que trata o Art. 264 da Lei da S.A.:

“Art. 264. Na incorporação, pela controladora, de companhia controlada, a justificação, apresentada à assembléia-geral da controlada, deverá conter, além das informações previstas nos arts. 224 e 225, o cálculo das relações de substituição das ações dos acionistas não controladores da controlada com base no valor do patrimônio líquido das ações da controladora e da controlada, avaliados os dois patrimônios segundo os mesmos critérios e na mesma data, a preços de mercado, ou com base em outro critério aceito pela Comissão de Valores Mobiliários, no caso de companhias abertas.

§ $1^{\text {o }}$ A avaliação dos dois patrimônios será feita por 3 (três) peritos ou empresa especializada e, no caso de companhias abertas, por empresa especializada.

$\S 2^{\underline{0}}$ Para efeito da comparação referida neste artigo, as ações do capital da controlada de propriedade da controladora serão avaliadas, no patrimônio desta, em conformidade com o disposto no caput.

$\S 3^{\circ}$ Se as relações de substituição das ações dos acionistas não controladores, previstas no protocolo da incorporação, forem menos vantajosas que as resultantes da comparação prevista neste artigo, os acionistas dissidentes da deliberação da assembléia-geral da controlada que aprovar a operação, observado o disposto nos arts. 137, II, e 230, poderão optar entre o valor de reembolso fixado nos termos do art. 45 e o valor do patrimônio líquido a preços de mercado.

$\S 4^{\circ}$ Aplicam-se as normas previstas neste artigo à incorporação de controladora por sua controlada, à fusão de companhia controladora com a controlada, à incorporação de ações de companhia controlada ou controladora, à incorporação, fusão e incorporação de ações de sociedades sob controle comum. 
$\S 5^{\circ} \mathrm{O}$ disposto neste artigo não se aplica no caso de as ações do capital da controlada terem sido adquiridas no pregão da bolsa de valores ou mediante oferta pública nos termos dos artigos 257 a $263 . "$

No texto do Parecer, a CVM elenca os deveres dos administradores conforme o artigo 154, que prevê que o administrador deve exercer suas funções "para lograr os fins e no interesse da companhia", sendo-lhe vedado faltar a esse dever "para a defesa dos interesses dos que o elegeram".

Convoca, ainda, o artigo 155, o qual determina que o administrador deve "lealdade à companhia" e não a terceiros. Concluindo que, os administradores das controladas devem negociar as operações de fusão, incorporação e incorporação de ações em benefício de todos os seus acionistas e não apenas do controlador.

Trás a baila o artigo 153, com a previsão que os administradores devem buscar com "o cuidado e diligência que todo homem ativo e probo costuma empregar na administração dos próprios negócios". Concluindo que, os administradores das companhias controladas devem negociar as operações de fusão, incorporação e incorporação de ações com a mesma prudência, cautela e, sobretudo, empenho que negociariam uma operação similar envolvendo uma empresa da qual fossem os únicos proprietários.

Considerou também, para edição do parecer em questão, a previsão do artigo 245 que determina que o administrador deve zelar para que as operações envolvendo sociedades coligadas, controladora ou controlada, "observem condições estritamente comutativas".

Todos os dispositivos legais acima mencionados serviram de base, para a edição dos itens de orientação do parecer, que passamos a transcrever: 
“i) a relação de troca e demais termos e condições da operação devem ser objeto de negociações efetivas entre as partes na operação;

ii) o início das negociações deve ser divulgado ao mercado imediatamente, como fato relevante, a menos que o interesse social exija que a operação seja mantida em sigilo;

iii) os administradores devem buscar negociar a melhor relação de troca e os melhores termos e condições possíveis para os acionistas da companhia;

iv) os administradores devem obter todas as informações necessárias para desempenhar sua função;

v) os administradores devem ter tempo suficiente para desempenhar sua função;

vi) as deliberações e negociações devem ser devidamente documentadas, para posterior averiguação;

vii) os administradores devem considerar a necessidade ou conveniência de contratar assessores jurídicos e financeiros;

viii) os administradores devem se assegurar de que os assessores contratados sejam independentes em relação ao controlador e remunerados adequadamente, pela companhia;

ix) os trabalhos dos assessores contratados devem ser devidamente supervisionados;

$\mathrm{x})$ eventuais avaliações produzidas pelos assessores devem ser devidamente fundamentadas e os respectivos critérios, especificados;

xi) os administradores devem considerar a possibilidade de adoção de formas alternativas para conclusão da operação, como ofertas de aquisição ou de permuta de ações;

xii) os administradores devem rejeitar a operação caso a relação de troca e os demais termos e condições propostos sejam insatisfatórios; 
xiii) a decisão final dos administradores sobre a matéria, depois de analisá-la com lealdade à companhia e com a diligência exigida pela lei, deve ser devidamente fundamentada e documentada; e

xiv) todos os documentos que embasaram a decisão dos administradores devem ser colocados à disposição dos acionistas, na forma do art. $3^{\circ}$ da Instrução CVM n ${ }^{\circ} 319$, de 3 de dezembro de 1999.

Além disso, seguindo a experiência internacional acerca da interpretação dos deveres fiduciários dos administradores, a CVM recomenda que:

i) um comitê especial independente seja constituído para negociar a operação e submeter suas recomendações ao conselho de administração, observando as orientações contidas no parágrafo anterior; ou

ii) a operação seja condicionada à aprovação da maioria dos acionistas nãocontroladores, inclusive os titulares de ações sem direito a voto ou com voto restrito.

$\mathrm{Na}$ formação do comitê especial independente acima referido, a CVM recomenda a adoção de uma das seguintes alternativas:

i) comitê composto exclusivamente por administradores da companhia, em sua maioria independentes;

ii) comitê composto por não-administradores da companhia, todos independentes e com notória capacidade técnica, desde que o comitê esteja previsto no estatuto, para os fins do art. 160 da Lei ${ }^{\circ}$ 6.404, de 1976; ou

iii) comitê composto por: (a) um administrador escolhido pela maioria do conselho de administração; (b) um conselheiro eleito pelos acionistas não-controladores; e (c) um terceiro, administrador ou não, escolhido em conjunto pelos outros dois membros.

A independência dos membros do comitê especial não pode ser determinada de antemão, devendo ser examinada a cada caso. De qualquer modo, a CVM presumirá a independência, salvo demonstração em contrário, de pessoas que atendam à 
definição de "conselheiro independente" prevista no Regulamento do Novo Mercado da Bolsa de Valores de São Paulo.”

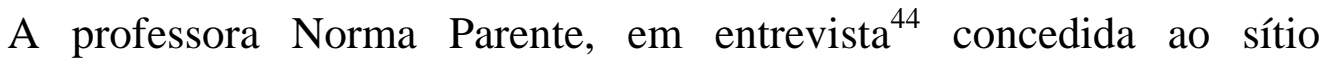
eletrônico "Transparência e Governança", pontua algumas vantagens e desvantagens trazidas pelo Parecer de orientação 35/08, como veremos a seguir:

"O parecer 35 tem a seu favor o fato de elencar os deveres de diligencia dos administradores das empresas envolvidas em operações de incorporação entre empresas ligadas, portanto serve como um guia para tais administradores. Porém, na prática, muitos administradores apenas seguem formalmente e muito resumidamente aquilo que está ali estabelecido.”

Na prática, verificamos que após a edição desse parecer, a autarquia acabou pacificando a questão de conflito no âmbito dos administradores, considerando as instruções nele contidas.

\footnotetext{
${ }^{44} \mathrm{http} / / / \mathrm{www} \cdot \operatorname{transparenciaegovernanca.com} . \mathrm{br} / \mathrm{TG} / \mathrm{index} . \mathrm{php}$ ?option=com_content\&view=article\&id $=119 \&$ Itemid $=118$
} 


\section{CONCLUSÃO}

Após a análise das posições e discusões mais relevantes sobre o tema do conflito de interesses, chegamos a conclusão que o desenvolvimento do país e a modernização de suas estruturas são caminhos inevitáveis. O aprimoramento das relações ocorridas no âmbito das sociedades anônimas se confunde com o próprio desenvolvimento do capitalismo e do mercado. Sobre a questão, são precisos os autores Alfredo Lamy filho e Bulhões Pedreira:

“(...) um instrumento admirável, de capacidade ilimitada para mobilizar capitais e congregar técnicas e pessoas na consecução de um objetivo em comum, [a sociedade anônima] tornou viáveis os gigantescos empreendimentos que caracterizam o estagio de desenvolvimento econômico de nossas dias." ${ }^{45}$

Por este fator, as relações que ocorrem no âmbito das sociedades anônimas atingem não apenas os seus investidores e stakeholders, mas também a sociedade como um todo. Portanto, é compreensível que a doutrina moderna e a jurisprudência estejam cada vez mais interessadas nas questões relacionadas a estas questões.

Quando falamos especificamente sobre o tema de conflito de interesses, verificamos que ainda existem divergências significativas na doutrina e na CVM. A autarquia tem mudado de entendimento de acordo com composição do seu órgão colegiado, e vem apresentando decisões diametralmente opostos para casos que apresentam forte semelhança.

Todavia, quando falamos da análise do conflito de interesses no âmbito dos administradores das empresas, verificamos que após a edição do Parecer de Orientação 35/08, a questão vem sendo decidida em seus moldes e a AVM têm exigido a sua observância.

\footnotetext{
${ }^{45}$ FILHO, Alfredo Lamy e PEDREIRA, José Luiz Bulhões, in Direito das Companhias, vol. 1, Rio de Janeiro, ed. Forense.
} 
Quando analisamos a questão sob a ótica do judiciário, verificamos que não há consolidada qualquer linha de entendimento sobre a matéria, sejam nas instâncias ordinárias ou superiores. A ausência de posicionamento firme, seja na doutrina na CVM ou poder judiciário, reforça a importância dos estudos nessa área.

Portanto, verifica-se que as regras aplicadas ãs questões relacionadas ao conflito de interesse, não podem ser interpretadas como norma estática e isolada dentro do sistema jurídico brasileiro. As questões relevantes devem ser verificadas caso a caso, inclusive através de seus impactos e circunstâncias posteriores para a sociedade. O foco deve ser ampliado para que a eventual solução esteja sempre abalizada pelo ordenamento ordinário trazido pela Lei 6.404/76, assim como os valores e princípios constitucionais do país. 


\section{BIBLIOGRAFIA}

PARENTE, Norma, in O Direito Empresarial, ed. Método, 2005.

COMPARATO, Fabio Konder e FILHO, Calisto Salomão, O Poder de Controle na Sociedade Anônima, Rio de Janeiro, ed. Forense, 5a edição, 2008.

RDM, Revista de Direito Mercantil n ${ }^{\circ} 128$.

SOUZA, Thelma Mesquita Garcia e, Governança Corporativa e o Conflito de interesses nas Sociedades Anônimas, São Paulo, ed. Atlas, 2005.

FRANÇA, Erasmo Valladão Azevedo e Novaes e, Direto Societário Contemporâneo I, ed. Quartier Latin, São Paulo, 2009.

NETO, Alfredo Sérgio Lazzarechi, Lei das Sociedades por Ações Anotada, ed. Saraiva, $2^{a}$ edição, 2008.

MARTINS, Ivandra Gandra da Silva, Comentários à Lei das Sociedades Anônimas, ed. Forense.

MARTINS, Fran, Comentários à Lei das Sociedades Anônimas, vol. 2. ed. Forense, Rio de Janeiro, 1978.

TOLEDO, Paulo Fernandes Campos Salles de, O Conselho de Administração na Sociedade Anônima, São Paulo, ed. Atlas, $2^{a}$ edição, 1999.

BATAlHA, Wilson de Souza Campos, Comentários à Lei das Sociedades Anônimas, vol. 2, ed. Forense, 1977.

LACERDA, J. C. de, Comentários à Lei das Sociedades Anônimas, ed. Saraiva, 1978 - v.3 (arts. 121 a 165); Coordenação de Arnoldo Wald

CASTRO, Rodrigo Monteiro de, ARAGÃO, Leandro Santos de, Sociedade Anônima 30 anos da Lei 6.404/76, São Paulo, ed. Quatier Latin, 2007. 
RIBEIRO, Renato Ventura. Direito de Voto nas Sociedades Anônimas, São Paulo: Quartier Latin, 2009.

FILHO, Alfredo Lamy e PEDREIRA, José Luiz Bulhões, in Direito das Companhias, vol. 1, Rio de Janeiro, ed. Forense, 2009.

CAMPOS, Luiz Antonio Sampaio. In FILHO, Alfredo Lamy e PEDREIRA, José Luiz Bulhões. Direito das Companhias. vol. 1, Rio de Janeiro: Forense, 2009.

CARVALHOSA, Modesto e LATORRACA, Nilton, Comentários à Lei das Sociedades Anônimas, vol. 3, São Paulo: ed. Saraiva, 1997.

CARVAlHOSA, Modesto, Comentários à Lei das Sociedades Anônimas, vol. $2^{\circ}, 4^{\mathrm{a}}$ edição, $2^{\mathrm{a}}$ tiragem, São Paulo: ed. Saraiva, 2009. 